\title{
A review on speciation of iodine-129 in the environmental and biological samples
}

Hou, Xiaolin; Hansen, Violeta; Aldahan, Ala; Possnert, Göran; Lind, Ole Christian; Lujaniene, Galina

Published in:

Analytica Chimica Acta

Link to article, DOI:

10.1016/j.aca.2008.11.013

Publication date:

2009

Link back to DTU Orbit

Citation (APA):

Hou, X., Hansen, V., Aldahan, A., Possnert, G., Lind, O. C., \& Lujaniene, G. (2009). A review on speciation of iodine-129 in the environmental and biological samples. Analytica Chimica Acta, 632(2), 181-196.

https://doi.org/10.1016/j.aca.2008.11.013

\section{General rights}

Copyright and moral rights for the publications made accessible in the public portal are retained by the authors and/or other copyright owners and it is a condition of accessing publications that users recognise and abide by the legal requirements associated with these rights.

- Users may download and print one copy of any publication from the public portal for the purpose of private study or research.

- You may not further distribute the material or use it for any profit-making activity or commercial gain

- You may freely distribute the URL identifying the publication in the public portal 


\title{
A Review on Speciation of Iodine-129 in the Environmental and Biological Samples
}

\author{
${\text { Xiaolin } \mathrm{Hou}^{1{ }^{*}} \text {, Violeta Hansen }}^{1)}$, Ala Aldahan ${ }^{2)}$, Göran Possnert ${ }^{3)}$, Ole Christian Lind ${ }^{4)}$ \\ Galina Lujaniene ${ }^{5)}$
}

1) Risø National Laboratory for Sustainable Energy, NUK-202, Technical University of Denmark, DK-4000 Roskilde, Denmark

2) Department of Earth Science, Uppsala University, SE-758 36 Uppsala, Sweden

3) Tandem Laboratory, Uppsala University, SE-751 21 Uppsala, Sweden

4) Norwegian University of Life Science, N-1432, Ås, Norway

5) Institute of Physics, Savanoriu 231, LT-0230 Vilnius, Lithuania

* Corresponding author: E-mail: xiaolin.hou@risoe.dk; Fax: +45-4677-5347, Tel: +45-4677-5357 


\section{Content}
Abstract
1. Introduction
2. Iodine in environment and its speciation

2.1 Speciation of iodine in water

2.2 Speciation of iodine in biological samples

2.3 Speciation of iodine in foodstuff and environmental samples

2.4 Speciation of iodine in atmosphere

2.5 Speciation of iodine in soil and sediment

3. Sources, inventory, and concentration level of ${ }^{129} \mathrm{I}$ in the environment

4. Analytical methods for the determination of ${ }^{129} \mathrm{I}$

4.1 Gamma and X-ray spectrometry

4.2 Liquid scintillation counting (LSC)

4.3 Neutron activation analysis (NAA)

4.4 Accelerator mass spectrometry (AMS)

4.5 Inductively coupled plasma mass spectrometry (ICP-MS)

5. Speciation analysis of ${ }^{129} \mathrm{I}$ in the environment and its application

5.1 Speciation of ${ }^{129} \mathrm{I}$ in water

5.2 Speciation of ${ }^{129} \mathrm{I}$ in atmosphere

5.3 Speciation of ${ }^{129} \mathrm{I}$ in soil and sediment

5.4 Speciation of ${ }^{129} \mathrm{I}$ in biological samples

6. Bioavailability and radiation toxicity of ${ }^{129} \mathrm{I}$

7. Summary and perspectives 


\begin{abstract}
As a long-lived beta-emitting radioisotope of iodine, ${ }^{129} \mathrm{I}$ is produced both naturally and as a result of human nuclear activities. At present time, the main part of ${ }^{129} \mathrm{I}$ in the environment originates from the human nuclear activity, especially the releases from the spent nuclear fuel reprocessing plants, the ${ }^{129} \mathrm{I} /{ }^{127} \mathrm{I}$ ratios have being reached to values of $10^{-10}-10^{-4}$ in the environment from $10^{-12}$ in the pre nuclear era. In this article, we review the occurrence, sources, inventory, and concentration level of ${ }^{129} \mathrm{I}$ in environment and the method for speciation analysis of ${ }^{129} \mathrm{I}$ in the environment. Measurement techniques for determination of ${ }^{129} \mathrm{I}$ are presented and compared. An overview of applications of ${ }^{129} \mathrm{I}$ speciation in various scientific disciplines such as radiation protection, waste depository, and environmental sciences is given. In addition, the bioavailability and radiation toxicity (dose to thyroid) of ${ }^{129}$ I are discussed.
\end{abstract}

Key words: Iodine-129, speciation analysis, tracer, bioavailability, environmental sample. 


\section{Introduction}

Iodine occurs as a trace element in the Earth's crust, with an average abundance of $0.45 \mathrm{mg}$ $\mathrm{kg}^{-1}$. Most of iodine $(>70 \%)$ in the Earth's surface environment exists in the oceans with a concentration range between 45 and $60 \mathrm{ng} / \mathrm{ml}[1,2]$. The only stable isotope of iodine is ${ }^{127} \mathrm{I}$ and the most long-lived radioisotope $(15.7 \mathrm{My})$ is ${ }^{129} \mathrm{I}$, which is also the only naturally occurring radioisotope of iodine (Table 1). Human nuclear activity has produced and released a large amount of ${ }^{129} \mathrm{I}$ to the environment thus elevating the ${ }^{129} \mathrm{I} /{ }^{127} \mathrm{I}$ ratio by at least two orders of magnitude compared with the natural values. Due to the long half-life and high mobility with its near conservative behavior in stored radioactive waste, ${ }^{129} \mathrm{I}$ is an important radionuclide in the waste management.

In order to assess short- and long-term consequences of radioactive contamination in the environment, information on on the distribution of radionuclide species influencing mobility and biological uptake is needed [3]. Such information can be obtained by means of radionuclide speciation analysis, which can be defined as the identification and quantification of a radionuclide species in a sample. Information on total concentration (without speciation) alone is not sufficient to evaluate the potential impact of radioactive pollutants in the environment and consequently their bioavailability. Speciation analysis thus provides realistic picture about the radionuclide transport mechanisms in the environment and to the human body, as well as accurate risk assessments. Despite the significance of elemental speciation analysis, there are many difficulties associated with achieving universally accepted analytical methods as well as problems related to sampling and storage.

${ }^{129} \mathrm{I}$ is one of key radionuclides in the nuclear waste depository, ${ }^{129} \mathrm{I}$ has also been shown a very useful isotope for the age dating [4,5], a suitable oceanographic tracer for studying transport and exchange of water mass [6-15], as well as a useful environmental tracer for investigating geochemical cycle of stable iodine [16-19]. Knowledge on the speciation of ${ }^{129} \mathrm{I}$ is a key issue for safety assessment of radioactive waste repositories, for estimation of human exposure through multiple pathways, as well as its application as an environmental and oceanographic tracer. In this article, we present a review on the state-of-the-art speciation analysis methods available for ${ }^{129} \mathrm{I}$. 
Empirical data have shown different ratios of ${ }^{129} \mathrm{I} /{ }^{127} \mathrm{I}$ for the different chemical species in water, soil, sediment [20-23], implying that the speciation of anthropogenic ${ }^{129} \mathrm{I}$ in the environment is different compared to the speciation of stable iodine. The concentration of ${ }^{129} \mathrm{I}$ in the environmental samples is normally 4-12 orders of magnitude lower than that of stable iodine, for this reason the analytical methods, including the species separation and analytical techniques for the stable iodine $\left({ }^{127} \mathrm{I}\right)$ can not be directly used for ${ }^{129} \mathrm{I}$. The speciation of stable ${ }^{127} \mathrm{I}$ has been widely investigated in the environmental and biological samples; a few review articles related to the speciation of stable iodine are available [1, 24-30]. However, the investigation of ${ }^{129}$ I speciation in the environmental, especially biological samples is still very limited. To our best knowledge, a comprehensive review article on speciation of ${ }^{129} \mathrm{I}$ has not been published. This article aims to review the occurrence, sources, environmental inventory, distribution, analytical method and speciation analysis of ${ }^{129} \mathrm{I}$ in environmental samples. The bioavailability of ${ }^{129} \mathrm{I}$ and its radiation toxicity are also discussed.

\section{Iodine in the nature and its speciation}

Iodine is widespread trace element in the hydrosphere, lithosphere, atmosphere and biosphere. Oceans are considered the main source of iodine (concentration at $45-60 \mathrm{ng} \mathrm{mL}^{-1}$ ) to the continental environments, which is back ventilated to the oceans by runoff at concentration of about $1-3 \mathrm{ng} \mathrm{mL} \mathrm{L}^{-1}$ in fresh water. The lowest iodine concentration was observed in atmosphere (1-100 $\mathrm{ng} \mathrm{m}^{-3}$ total concentration) [20,31], while the iodine concentration in precipitation $\left(1-6 \mathrm{ng} \mathrm{mL}^{-1}\right)$, which is removed from the atmosphere, is relatively higher [16, 31]. In the continental environments, the oceanic iodine is commonly trapped by soils, sediments and biota, whereas another source of iodine is supplied by erosion of bedrock. Iodine concentration in soil ranges from $0.5 \mu \mathrm{g} / \mathrm{g}$ to $40 \mu \mathrm{g} / \mathrm{g}$ with common concentration of $1-3 \mu \mathrm{g} \mathrm{g}^{-1}$, and the organic soils normally has a higher iodine concentration [32-33]. Generally, sedimentary rocks, especially surface sea sediments contain comparatively high concentrations of iodine (1-2000 $\left.\mu \mathrm{g} \mathrm{g}^{-1}\right)$ compared to metamorphic and magmatic rocks $\left(<0.1 \mu \mathrm{g} \mathrm{g}^{-1}\right)$ [2]. In the biosphere, iodine concentrations depend on its availability and concentration in the surrounding environment. High concentration of iodine was observed in seaweeds (10-6000 $\mathrm{Mg} \mathrm{g}^{-1}$ dry weight), of which brown algae shows the highest values (100-6000 $\left.\mu \mathrm{g} \mathrm{g}^{-1}\right)$ [34]. Terrestrial plants normally have lower iodine concentrations $\left(<1 \mu \mathrm{g} \mathrm{g} \mathrm{g}^{-1}\right)$ than the marine ones. In mammals, iodine is mainly concentrated to thyroid, with concentration of 0.5-5 mg 
$\mathrm{g}^{-1}$ dry weight) [35-36], while iodine concentration in other tissues is normally much lower $(<1 \mu \mathrm{g}$ $\mathrm{g}^{-1}$ dry weight) [37].

Iodine is an electronegative element with oxidation states of $-1,0,+1,+3,+5$, and +7 and exists in multiform in aqueous solution. Iodine is a redox sensitive element forming a wide variety of organic and inorganic compounds and the most common inorganic forms of iodine are $\mathrm{I}^{-}$(iodide), $\mathrm{HOI}$ (hypoiodous acid), $\mathrm{I}_{2}$ (elemental iodine), and $\mathrm{IO}_{3}{ }^{-}$(iodate) in natural environmental Eh-pH conditions (Fig.1) [38-39]. As a biophilic element, iodine occurs in many organic compounds in nature such as alkyl iodide and is incorporated in organic matters such as proteins, polyphenols and humic substances [40-43].

\subsection{Speciation of iodine in water}

Speciation of iodine in natural water depends on several parameters including water chemistry, $\mathrm{pH}, \mathrm{Eh}$, temperature and organic productivity. In seawater, iodine mainly exists as iodate, iodide and minor organic iodine [1]. Distribution of iodine species in seawater varies with depth and geographic location. In anoxic water, most of iodine exists as iodide, e.g. in the Baltic Sea and the Black Sea [23, 44-45], while in oxygenated/oxic water, such as ocean water, the dominated species of iodine is iodate. The concentration in the ocean ranges at $<1 \sim 25 \mathrm{ng} \mathrm{mL}^{-1}$ for iodide and $25 \sim 60$ $\mathrm{ng} \mathrm{mL} \mathrm{m}^{-1}$ for iodate. Iodide maximum is often found in surface water while iodide decreases to $<1 \mathrm{ng}$ $\mathrm{mL}^{-1}$ below the euphotic zone. Relatively high iodide concentration is normally found in coastal and estuary areas $[15,46]$.

Organic iodine was reported in coastal and estuary area, corresponding to $5-40 \%$ of total dissolved iodine [47-48]. Some specific organic iodine compounds have been identified, including mainly volatile compounds, such as $\mathrm{CH}_{3} \mathrm{I}, \mathrm{CH}_{2} \mathrm{ClI}, \mathrm{CH}_{2} \mathrm{I}_{2}$ and $\mathrm{CH}_{3} \mathrm{CH}_{2} \mathrm{CH}_{2} \mathrm{I}$ [42-43]. Although the concentration of organic iodine in seawater is low, it plays a very important role in the global geochemical cycle of iodine. The transfer of iodine from the oceans to the atmosphere, and further to the terrestrial environment, is thought to occur primarily through the emission of organic iodine hydrocarbon from the seawater [49]. These volatile organic iodine species were also suggested to contribute to ozone depletions in the lower stratosphere, particularly the marine boundary layer [5051] and cloud condensation in the lower troposphere [52]. In fresh water, such as rivers, lakes and rain, iodine exists also as iodide, iodate and organic iodine, but the relative concentration of organic iodine is higher compared to seawater [53-56]. 


\subsection{Speciation of iodine in biological foodstuff and environmental samples}

Iodine comprises a vital ingredient by the thyroid gland in mammals for the biosynthesis of the thyroid hormones triiodothyronine $\left(\mathrm{T}_{3}\right)$ and thyroxine $\left(\mathrm{T}_{4}\right)$. These hormones have an important influence on an extended range of biochemical reactions. Besides $\mathrm{T}_{3}$ and $\mathrm{T}_{4}$, iodine also occurs as monoiodotyrosin (MIT), diiodotyrosine (DIT), and reverse-triiodothyronine ( $\left.\mathrm{rT}_{3}\right)$, which are mainly bound with proteins in thyroid as well as blood, but they function as free $T_{3}$ and $T_{4}$. In addition to thyroid, iodine is also distributed in many other tissues, mainly bound with proteins [57]. In urine, iodine mainly exists as iodide, with small amount of organic iodine. The element was also found as iodide, MIT, DIT, $\mathrm{T}_{4}, \mathrm{~T}_{3}, \mathrm{rT}_{3}$ and other unknown species in fish flesh [58].

Breast milk samples taken from a selected group of European women contain $95 \pm 60 \mathrm{ng}$ iodine $\mathrm{mL}^{-1}$ milk in average. In addition, total iodine varies according to lactation state, beginning at $60 \mathrm{ng}$ $\mathrm{mL}^{-1}$ at $2^{\text {nd }}$ day (postpartum), reaching $100 \mathrm{ng} \mathrm{mL}^{-1}$ at $3^{\text {rd }}$ day, and decreasing to $80 \mathrm{ng} \mathrm{mL}^{-1}$ (6 $6^{\text {th }}$ day) or $60 \mathrm{ng} \mathrm{mL} L^{-1}$ constantly from $9^{\text {th }}$ day to $60^{\text {th }}$ Day. More than $80 \%$ of iodine in human milk presents as iodide, and the rest occurs as organic iodine [59-61].

In seaweed, 9 99\% of iodine is water-soluble depending on the seaweed species, the highest water soluble iodine was observed in brown algae and lowest in green algae. In the water leachate of seaweed, iodine exists mainly as iodide, the percentage of organic iodine ranges in 5 40\% and the iodate is less than $5 \%$. In biological macromolecules, iodine is mainly bound with proteins, ployphenol and pigments [42-43], and iodine in the enzymatic hydrolyzed protein exists as MIT and DIT [62]. Recently, Küpper et al. [63] directly analyzed a brown seaweed (Laminaria digitata) using X-ray absorption spectroscopy (iodine K-edge), and confirmed that mainly accumulated iodine exists as iodide. Their experiments also showed that iodide in seaweed readily scavenges a variety of reactive oxygen species; it is therefore proposed that the biological role of iodide in the seaweed is that of an inorganic antioxidant. It was also observed that on thallus surface and in appoplast of the seaweed, iodide detoxifies both aqueous oxidants and ozone, the latter resulting in the release of high level of molecular iodine $\left(\mathrm{I}_{2}\right)$ and consequent formation of hygroscopic iodine oxides (IO.) leading to particle formation, which are precursor to cloud condensation nuclei. Some experiments have showed a significantly increasing $\mathrm{I}_{2}$ and particle concentrations in a culture chamber of brown seaweed, the released $\mathrm{I}_{2}$ from the brown seaweed is therefore linked with the formation of coastal new particles and cloud condensation nuclei [64-67].

\subsection{Speciation of iodine in atmosphere}


Total concentration of iodine in the atmosphere ranges from 1 to $100 \mathrm{ng} \mathrm{m}^{-3}$ where a high iodine concentration was observed in urban area due to the combustion of oil and coal, as well as coastal area due to emission of gaseous iodine from algae, seawater, as well as sea spray [58, 63-65, 68-69]. In the atmosphere, iodine exists as particle associated iodine (particulate iodine), inorganic gaseous iodine $\left(\mathrm{I}_{2}, \mathrm{HI}, \mathrm{HOI}\right)$ and organic gaseous iodine $\left(\mathrm{CHI}_{3}, \mathrm{CH}_{2} \mathrm{I}_{2}, \mathrm{CH}_{3} \mathrm{CH}_{2} \mathrm{CH}_{2} \mathrm{I}\right.$, etc.); their concentrations vary with various parameters, such as location, season and climate [31, 70-72]. Soluble species of iodine in the aerosol exist as iodide, iodate and organic iodine [54, 73-75]. The photolysis of volatile gaseous iodine could generate active I which would interact with atmospheric species such as $\mathrm{O}_{3}, \mathrm{H}_{\mathrm{x}} \mathrm{O}_{\mathrm{y}}$, and $\mathrm{NO}_{\mathrm{x}}$ to produce $\mathrm{IO}, \mathrm{HOI}, \mathrm{ION}_{2}$ and $\mathrm{I}_{2}$. Production and cycling back to I could cause catalytic removal of troposphere $\mathrm{O}_{3}$. A mixing ratio of IO up to $6.6 \mathrm{ppt}$ has been measured at mace Head, Ireland [76]. A relative large amount of molecular iodine $\left(\mathrm{I}_{2}\right)$ may be emitted from seaweed, the released $\mathrm{I}_{2}$ could be converted to active $\mathrm{I}$, and then react with $\mathrm{O}_{3}$ to form $\mathrm{IO}$, which was supposed to be a key route to produce new particles [63].

\subsection{Speciation of iodine in soil and sediment}

Iodine speciation in soil and sediment is normally investigated by sequential extraction, where results showed that most of iodine in soil and sediment is associated to organic matters, mainly humic substances. Part of iodine is also adsorbed on oxides and hydroxides of iron and manganese. The fraction of soluble iodine in soil and sediment comprises minor part of soil iodine and varies with the soil chemistry [21-22, 77]. Iodine in soil solution exists as iodide, iodate, and humic substance (humic acid, and fulvic acid) depending upon the soil condition. It was reported that iodate is the dominant specie of iodine in soil solution under non-flooded oxidizing soil condition $(85 \%)$, while under the flooded condition (anoxic); the dominant specie is iodide [78].

\section{Sources, inventory, and concentration level of ${ }^{129} I$ in the environment}

Although all ${ }^{129} \mathrm{I}$ formed in the primordial nucleosynthesis has decayed to ${ }^{129} \mathrm{Xe}$ (stable), natural processes including the reaction of high energy particles (cosmic rays) with xenon in the upper atmosphere, spontaneous fission of ${ }^{238} \mathrm{U}$, thermal neutron-induced fission of ${ }^{235} \mathrm{U}$ and to a lesser extent the neutron activation reactions, ${ }^{128} \mathrm{Te}(\mathrm{n}, \gamma){ }^{129} \mathrm{I}$ and ${ }^{130} \mathrm{Te}(\mathrm{n}, 2 \mathrm{n}){ }^{129} \mathrm{I}$, contribute to a steady state concentration of ${ }^{129} \mathrm{I}$. The estimated atom ratios of ${ }^{129} \mathrm{I} /{ }^{127} \mathrm{I}$ in the marine environment are $3 \times 10^{-13} \sim 3 \times 10^{-12}$ and even lower ratio of $10^{-15} \sim 10^{-14}$ in the lithosphere [79-80]. These ranges 
correspond to a steady state inventory of about $180 \mathrm{~kg}{ }^{129} \mathrm{I}$ in the hydrosphere and about $60 \mathrm{~kg}$ in lithosphere (total at about $250 \mathrm{~kg}$ ). A representative ratio of ${ }^{129} \mathrm{I}^{127} \mathrm{I}$ at $1.5 \times 10^{-12}$ is commonly considered in the hydrosphere which has been based on measurement of marine sediment samples [81-83].

Since 1945, large amounts of ${ }^{129} \mathrm{I}$ has been produced and released to the environment by human nuclear activities. ${ }^{129} \mathrm{I}$ is mainly produced by neutron-induced fission of ${ }^{235} \mathrm{U}$ and ${ }^{239} \mathrm{Pu}$ in the explosion of nuclear devices, as well as in the operation of nuclear reactors for research and power production. An approximate rate of $0.17 \mathrm{~g}$ and $0.28 \mathrm{~g}$ of ${ }^{129} \mathrm{I}$ per kiloton TNT equivalent is produced from fission of ${ }^{235} \mathrm{U}$ and ${ }^{239} \mathrm{Pu}$, respectively in a nuclear explosion. Total yield of about 540 megatons TNT equivalent was produced from nuclear weapons tests in the atmosphere or at ground level during the period from 1945 to 1975 . These tests have released about $57 \mathrm{~kg}$ of ${ }^{129} \mathrm{I}$ to the environment [80]. The ${ }^{129} \mathrm{I}$ injected to the atmosphere, especially into the stratosphere, has a relatively long residence time, which implies mixing and fallout over a large area. A globally elevated ${ }^{129} \mathrm{I}$ level has been observed in the environment [26] resulting in a high ratio of ${ }^{129} \mathrm{I} /{ }^{127} \mathrm{I}$, particularly in the northern hemisphere. A relatively lower ${ }^{129} \mathrm{I} /{ }^{127} \mathrm{I}$ value was observed in the southern hemisphere $\left(10^{-11}-10^{-9}\right)$ with the lowest ratio in the equatorial regions $\left(10^{-11}-10^{-10}\right)$. In general, the ${ }^{129} \mathrm{I} /{ }^{127} \mathrm{I}$ ratio has been increased to $10^{-11}-10^{-10}$ in the marine environment and $10^{-11}-10^{-9}$ in terrestrial environment due to the nuclear weapons testing [26, 35, 77, 84-91].

Routine operation of the nuclear reactors, for power production and research, may release ${ }^{129} \mathrm{I}$ to the environment, but no significantly increased concentration was observed in the surrounding area of nuclear power plants [14]. Records of ${ }^{129}$ I releases from nuclear accidents are difficult to establish, mainly due to lack of contemporaneous measurement. The Windscale (10 Oct. 1957) and Three Mile Island (28 March 1979) accidents may have released some amount of ${ }^{129} \mathrm{I}$ to the environment, but it was not possible to be isolated from other signals [92]. A relatively better defined ${ }^{129} \mathrm{I}$ signal is documented from the Chernobyl accident in 1986 [93]. A high ${ }^{129}$ I level $\left({ }^{129} \mathrm{I} /{ }^{127} \mathrm{I}\right.$ ratio of $\left.10^{-6}\right)$ was measured in environmental samples collected from the Chernobyl accident contaminated area [22, 36, 88, 93-95]. A total release of ${ }^{129} \mathrm{I}$ from the Chernobyl accident was estimated to be $1.3-6 \mathrm{~kg}[93,96]$.

Commonly a large amount of ${ }^{129} \mathrm{I}$ is produced during the operation of a nuclear power reactor. The production efficiency of ${ }^{129} \mathrm{I}$ in the reactor depends on burn-up of the uranium fuel, which is corresponding to the power production of the reactor. It was estimated that about $7.3 \mathrm{mg}{ }^{129} \mathrm{I}$ is produced per MWd (megawatt day) [80]. About $9.3 \times 10^{9} \mathrm{MWd}$ of nuclear power has been 
produced in the world from 1980 to 2005, with a production of $368 \mathrm{GWe}$ in 2005 [97], it can be estimated that about $68000 \mathrm{~kg}{ }^{129} \mathrm{I}$ has been produced in the nuclear power reactors up to 2005 . However, most of ${ }^{129}$ I generated in the nuclear power production was kept in the spent fuel. The fuel elements were encased in cladding that prevented the release of gaseous radioiodine to the atmosphere, and only a small part of them was released to the environment by the reprocessing of the spent fuel.

During reprocessing of nuclear fuel (mainly by PUREX process), the fuel is first dissolved with acid $\left(\mathrm{HNO}_{3}\right)$. In this step, most of iodine is oxidized to volatile $\mathrm{I}_{2}$ and released from the fuel solution, which may be trapped and collected, while some part may be released from the reprocessing plant to the atmosphere [98-99]. The trapped ${ }^{129} \mathrm{I}$ in solution may be stored or discharged to the environment. The ${ }^{129} \mathrm{I}$ remained in the solution is extracted into the organic solvents during following extraction process using tri-n-butyl phosphate (TBP), where ${ }^{129}$ I may react with TBP and thus occurs in organic forms [100]. Many reprocessing plants have being operated since 1940's, and some of them are still in operation. The reprocessing plants at La Hague (France) and Sellafield (UK) are the largest. Until 2007, the La Hague reprocessing plant has discharged around $3800 \mathrm{~kg}{ }^{129} \mathrm{I}$ to the English Channel, and the Sellafield reprocessing plant has discharged $1400 \mathrm{~kg}{ }^{129} \mathrm{I}$ to the Irish Sea. Meanwhile these two reprocessing plants have also released $75 \mathrm{~kg}$ and $180 \mathrm{~kg}$ of ${ }^{129} \mathrm{I}$ to the atmosphere, respectively. Another European spent fuel reprocessing plant was located at Marcoule (France) which has also released comparable amount of ${ }^{129} \mathrm{I}\left(145 \mathrm{~kg}\right.$ ) to the atmosphere, but relatively small amount of liquid ${ }^{129} \mathrm{I}$ (45 kg) to the Rhone river. Annual discharges of ${ }^{129} \mathrm{I}$ from these three reprocessing plants are shown in Fig. 2 (Liquid discharges) and Fig. 3 (atmosphere releases) [7, 15 89, 101-102]. It can be seen that a similar amount of ${ }^{129} \mathrm{I}$ has been released to the atmosphere from the three reprocessing plants with a relative constant rate of each $\left(2-10 \mathrm{~kg} \mathrm{y}^{-1}\right)$. The marine discharges of ${ }^{129} \mathrm{I}$ from La Hague and Sellafield is smaller and relatively constant before $1990\left(<50 \mathrm{~kg} \mathrm{y}^{-1}\right)$, later on the discharge of ${ }^{129} \mathrm{I}$ increased significantly to about $250 \mathrm{~kg} / \mathrm{y}$ for La Hague and $80 \mathrm{~kg} / \mathrm{y}$ for Sellafield. As a consequence, the ${ }^{129} \mathrm{I}$ concentration in the Irish Sea, English Channel, North Sea, and Nordic Seas has significantly increased and the ${ }^{129} \mathrm{I} /{ }^{127} \mathrm{I}$ ratio in these seawater has elevated to values of $10^{-8}-10^{-5}[6-7,11-15,23$, 103-108]. Even high level of ${ }^{129} \mathrm{I}$ concentration with a ratio of ${ }^{129} \mathrm{I} /{ }^{127} \mathrm{I}$ at $10^{-6}-10^{-4}$ has been measured in the terrestrial samples collected near the reprocessing plants at La Hague, Marcoule and Sellafield [77, 105, 109]. These high ratios are attributed to local deposition of atmospheric releases of ${ }^{129} \mathrm{I}$ from the reprocessing plants. ${ }^{129} \mathrm{I}$ has also been released from other reprocessing 
plants mainly to atmosphere, in which Hanford reprocessing plant (USA) released about $260 \mathrm{~kg}{ }^{129} \mathrm{I}$ during its operation (1944-1972) [110] and about $14 \mathrm{~kg}$ during its resumed operation (1983-1988) [82]; reprocessing plant at Tokai, Japan released about $1.0 \mathrm{~kg}{ }^{129} \mathrm{I}$ since its operation from 1997 until 2005 [111-112]; about $1.1 \mathrm{~kg}$ of ${ }^{129} \mathrm{I}$ was released from the Karlsruhe reprocessing plant (WAK, Germany) during its operation (1971-1987) [113], and unknown amount of ${ }^{129} \mathrm{I}$ from reprocessing plants in Russia, China and India. An elevated ${ }^{129} \mathrm{I}$ levels with ${ }^{129} \mathrm{I} /{ }^{127} \mathrm{I}$ ratio of $10^{-6}-10^{-4}$ have been also reported in samples collected in the regions near the reprocessing plants at WAK, Germany, Hanford, USA, Tokai, Japan, and India [98,13-116].

Table 2 summarizes the sources, inventory and environmental level of ${ }^{129} \mathrm{I}$. It is clear that presently the main source of ${ }^{129} \mathrm{I}$ is the reprocessing plants at La Hague and Sellafield. However, the major part of ${ }^{129} \mathrm{I}$ produced in reactors around the world, mainly power reactor $(>90 \%)$, is still stored and pending for future reprocessing. At present, the different levels of ${ }^{129} \mathrm{I} /{ }^{127} \mathrm{I}$ in the environment are envisaged as $10^{-12}$ for the pre-nuclear era, $10^{-9}$ in slightly contaminated regions and $10^{-9}-10^{-6}$ in regions affected by the releases from the reprocessing plants. The highest ratio of ${ }^{129} \mathrm{I} /{ }^{127} \mathrm{I}$ at $10^{-6}-10^{-3}$ was found in regions locating at the vicinity $(<50 \mathrm{~km})$ of the reprocessing plants.

\section{Measurement of ${ }^{129} I$}

${ }^{129} \mathrm{I}$ decays by emitting $\beta$-particle with a maximum energy of $154.4 \mathrm{keV}$ and $\gamma$-ray of $39.6 \mathrm{keV}$ as well as X-rays (29-30 keV) (Table 1). It can therefore be measured by $\gamma$-X-spectrometry and $\beta$-counting using liquid scintillation counters (LSC). Neutron activation analysis (NAA) is another radiometric method for the determination of ${ }^{129} \mathrm{I}$. The method is based on neutron activation of ${ }^{129} \mathrm{I}$ to ${ }^{130} \mathrm{I}$, a short lived radionuclide, emitting high energy $\gamma$-rays (536 keV(99\%), $668.5 \mathrm{keV}(96 \%)$, and $739.5 \mathrm{keV}(82 \%))$, which is easily and efficiently measured by $\gamma$-spectrometry. Mass spectrometry, such as accelerator mass spectrometry (AMS) and inductively coupled plasma mass spectrometry (ICP-MS) has also been used for the determination of ${ }^{129}$ I. A summary of the most common used methods is presented below.

\subsection{Gamma and X-ray spectrometry}

Gamma and X-ray spectrometry have been used to measure ${ }^{129} \mathrm{I}$ in thyroid, urine, seaweed, and nuclear waste by using HpGe or plenary Si detector [104-106, 117-118]. This is based on the counting the $39.6 \mathrm{keV} \gamma$-ray or $29.46+29.48 \mathrm{keV}(58.1 \%) \mathrm{X}$-rays. Due to the low counting efficiency of gamma detector $(<2 \%)$, low $\gamma$-ray abundance $(7.5 \%)$, and high background, a 
detection limit of 20-200 mBq was obtained [104, 117-118] depending on the level of interfering radionuclide. In addition, due to the low energy of $\mathrm{X}-\gamma$ rays $(29-40 \mathrm{keV})$ and normally big sample used (50 -500 g), elaborative self-absorption correction has to be carried out in order to obtain accurate results. A chemical separation of iodine from the matrix and interfering radionuclides can improve the detection limit to around $20 \mathrm{mBq}$ when using gamma spectrometry. In addition, due to small size of the separated sample $(<20 \mathrm{mg})$, the self-absorption correction can be neglected.

\subsection{Liquid scintillation counting (LSC)}

Due to high beta energy of ${ }^{129} \mathrm{I}(154 \mathrm{keV})$, a better counting efficiency of LSC for ${ }^{129} \mathrm{I}(60$ 95\%) compared to X- $\gamma$ spectrometry $(<5 \%)$ can be obtained depending on the quench level. In this method, iodine has to be separated from the sample matrix as well as other radionuclides before counting. A detection limit of $10 \mathrm{mBq}$ has been reported [117].

\subsection{Neutron activation analysis}

Neutron activation analysis (NAA) was firstly proposed and applied in 1962 [79, 119] for the determination of ${ }^{129} \mathrm{I}$, which based on the following nuclear reaction:

\section{${ }^{129} I \stackrel{(n, \gamma), \sigma=30 b, I=27.6 b}{\longrightarrow}{ }^{130} I \stackrel{\beta^{-}, 12.3 h}{\longrightarrow}{ }^{130} \mathrm{Xe}$}

By measurement of activation product, ${ }^{130} \mathrm{I}$ (12.3 hours), decaying by emitting beta particles and gamma rays (Table 1), ${ }^{129} \mathrm{I}$ is determined. Using NAA, ${ }^{129} \mathrm{I}$ can be determined with a better sensitivity compared with the direct measurement due to the high specific radioactivity of ${ }^{130} \mathrm{I}$ and suitable gamma energies (418 KeV (34\%), 536.1 KeV (99\%), $668.5 \mathrm{KeV}(96 \%)$, and $739.5 \mathrm{KeV}$ $(82 \%))$. However, interfering nuclear reactions from some nuclides other than iodine isotopes may occur during production of ${ }^{130} \mathrm{I}$ in the samples. These nuclides include ${ }^{235} \mathrm{U},{ }^{128} \mathrm{Te}$, and ${ }^{133} \mathrm{Cs}$. Because of the extremely low concentration of ${ }^{129} \mathrm{I}$ in environmental samples $\left(10^{-17} \sim 10^{-11} \mathrm{~g} / \mathrm{g}\right)$, these interfering nuclides have to be removed from the sample before irradiation to avoid nuclear interference that will generate spurious results. The radioactivity produced from the activation products of the sample matrix elements, such as ${ }^{24} \mathrm{Na}$ and ${ }^{82} \mathrm{Br}$, is more than 10 orders of magnitude higher than that of ${ }^{130} \mathrm{I}$, which hinders the direct measurement of ${ }^{130} \mathrm{I}$ after irradiation. Bromine in particular, produces $\gamma$-rays of ${ }^{82} \mathrm{Br}$ that interferes with the measurement of ${ }^{130} \mathrm{I}$, which necessities a post-irradiation chemical purification to provide a necessary decontamination with respect to this nuclide. Besides ${ }^{129} \mathrm{I}$, stable iodine $\left({ }^{127} \mathrm{I}\right)$ can be simultaneously determined by fast neutron reaction 
${ }^{127} \mathrm{I}(\mathrm{n}, 2 \mathrm{n}){ }^{126} \mathrm{I}$. A typical analytical procedure for the determination of ${ }^{129}$ I by radiochemical NAA [120] is shown in Fig. 4.

For solid sample, such as soil, sediment, vegetations and tissues, alkali fusion/ashing method can be used for decomposition of sample, in which the sample is first mixed with alkali solution, and then ashed or fussed at $600^{\circ} \mathrm{C}$. Iodine is then leached from the decomposed sample using water. The experimental results have showed that the recovery of iodine in ashing or fusion procedure is higher than $80 \%$ [121]. A combustion method has also widely been used for the separation of iodine from solid samples [121-122]. In this method, sample is combusted at higher temperature $\left(>800^{\circ} \mathrm{C}\right)$, the released iodine, mainly as $\mathrm{I}_{2}$, is trapped with alkali solution $(\mathrm{KOH})$ or active charcoal. Iodine in the leachate or trapping solution is extracted with $\mathrm{CCl}_{4}\left(\right.$ or $\left.\mathrm{CHCl}_{3}\right)$ after acidified and oxidized to $\mathrm{I}_{2}$, and then back extracted with $\mathrm{H}_{2} \mathrm{SO}_{3}$. After conversion of separated iodine to $\mathrm{MgI}_{2}$, it is applied for neutron irradiation. Fig. 5 shows a commercial combustion facility, which can be used for separation of iodine from solid sample. For water sample including milk and urine, iodine can be separated by anion exchange method. In which, iodine is first converted to iodide and then absorbed by anion exchange resin (AG1) and separated from matrix elements. The iodide absorbed on resin is eluted by nitrate solution, and concentrated by extraction with $\mathrm{CCl}_{4}$ from the eluate $[16,23,36$, 123]. The separated iodine in small volume of water sample is converted to $\mathrm{MgI}_{2}$ similar to solid samples.

The pre-separated iodine as $\mathrm{MgI}_{2}$ or adsorbed in active charcoal is irradiated in a nuclear reactor for 2-12 hours and the irradiated samples is further purified by dissolution with acid and then extracted with $\mathrm{CCl}_{4}$. Iodide is then precipitated as $\mathrm{PdI}_{2}$ for gamma counting. The ${ }^{130} \mathrm{I}$ (from ${ }^{129} \mathrm{I}$ ) and ${ }^{126} \mathrm{I}$ (from ${ }^{127} \mathrm{I}$ ) are counted using an $\mathrm{HpGe}$ detector. By comparison with standard and correction for chemical yield during the chemical separation, the absolute contents of ${ }^{129} \mathrm{I}$ and ${ }^{127} \mathrm{I}$ in the samples are calculated.

${ }^{127} \mathrm{I}$ can also cause interference during the determination of ${ }^{129} \mathrm{I}$ by three continuous neutron capture reactions, ${ }^{127} \mathrm{I}(3 \mathrm{n}, \gamma){ }^{130} \mathrm{I}$. This interference varies as the square root of the neutron flux and increases with the length of the irradiation time. For irradiation of 10 hours in a thermal neutron flux of $4 \times 10^{13} \mathrm{n} \mathrm{cm}^{-2} \mathrm{~s}, 1 \mathrm{~g}$ of ${ }^{127} \mathrm{I}$ can produce ${ }^{130} \mathrm{I}$ equivalent to $7.7 \times 10^{-12} \mathrm{~g}$ of ${ }^{129} \mathrm{I}$. For a sample with ${ }^{129} \mathrm{I} /{ }^{127} \mathrm{I}$ ratio higher than $10^{-11}$, this interference can be corrected by simultaneous determination of ${ }^{127} I$ concentration via a fast neutron reaction of ${ }^{127} I(n, 2 n){ }^{126} I$. But, this interference limits the analysis of sample with ${ }^{129} \mathrm{I} /{ }^{127} \mathrm{I}$ ratio lower than $10^{-11}$. 
A large number of samples have been analyzed for ${ }^{129}$ I using NAA [13-14, 16, 22-23, 35-36, 77, $85-86,113-116,118-121]$, and NAA is also a main method used for the determination of ${ }^{129} \mathrm{I}$ in environmental samples besides AMS. A detection limit of $1 \mu \mathrm{Bq}$ (or $2 \times 10^{-13} \mathrm{~g}$, or $10^{9}$ atoms, or ${ }^{129} \mathrm{I} /{ }^{127} \mathrm{I}$ ratio of $10^{-10}$ ) has been reported [120].

\subsection{Accelerator mass spectrometry (AMS)}

Mass spectrometric techniques, including AMS, SIMS and ICP-MS, have also been used for ${ }^{129}$ I determination. Almost all AMS facilities can be understood as two mass spectrometers (called “injector" and "analyzer") linked with a tandem accelerator. Before measurement, iodine needs to be separated from the sample and prepared as AgI precipitate. The separation procedure used in the NAA can be also used for AMS. The separated iodine as iodide is then precipitated as AgI, which is dried and then mixed with Ag or Nb powder for AMS measurement. The iodine in AgI target is injected to the system as a negative ion by ion sputtering (e.g. using a $\mathrm{Cs}^{+}$primary ion source), $\mathrm{I}^{-}$ ions are easily formed in the sputter source, while ${ }^{129} \mathrm{Xe}^{-}$, the main isobaric interference, is unstable and decomposed rapidly thus having insignificant interference. The formed ${ }^{129} \mathrm{I}^{-}$and ${ }^{127} \mathrm{I}^{-}$negative ions are then accelerated to positive high-voltage terminal of a tandem accelerator where several electrons may be stripped off, converting negative ions to $\mathrm{I}^{5+}$ or $\mathrm{I}^{7+}$. The stripping process has the advantage that it dissociates molecular ions if enough electrons are stripped off which results in a further elimination of interferences from ${ }^{128} \mathrm{TeH}^{-}$and ${ }^{127} \mathrm{IH}_{2}^{-}$. The positively charged ions from the accelerator then pass through a magnetic analyzer, where the ions of ${ }^{129} \mathrm{I}$ and ${ }^{127} \mathrm{I}$ with a well defined combination of charge state and energy are selected, and directed to a detector. Furthermore, the higher energies of the ions after acceleration allow an additional separation of the wanted ions from possible background ions at the particle detector. The separated ${ }^{129} \mathrm{I}$ is detected by a combination of time-of-flight and silicon charged particle detectors or gas ionization energy detector. The instrumental background of ${ }^{129} \mathrm{I} /{ }^{127} \mathrm{I}$ down to $10^{-14}$ has been obtained [124]. The detection limit of ${ }^{129} \mathrm{I}$ depends on the chemical separation procedure and iodine carrier. Commonly a blank ${ }^{129} \mathrm{I} /{ }^{127} \mathrm{I}$ ratio of $1 \times 10^{-13}$ was reported, which corresponds to $10^{-9} \mathrm{~Bq}$ (or $10^{-16} \mathrm{~g}$ or $10^{5}$ atoms) ${ }^{129} \mathrm{I}$ for $1 \mathrm{mg}$ ${ }^{127} \mathrm{I}$ carrier, and the analytical uncertainty is lower than $10 \%$ for a ${ }^{129} \mathrm{I} /{ }^{127} \mathrm{I}$ ratio of $10^{-12}$ [124]. Due to the very high sensitivity, most of determinations of ${ }^{129} \mathrm{I}$ in environmental samples, especially low level geological samples, are now carried out by AMS. Actually, AMS is the only method for the determination of ${ }^{129} \mathrm{I}$ in the pre-nuclear age samples $\left({ }^{129} \mathrm{I} /{ }^{127} \mathrm{I}<10^{-10}\right)[4,6-12,15,17-18,26,52,39$, $45,56,82-84,89,90,94,103,108,126-128]$. AMS is a relative analytical method, ${ }^{129} \mathrm{I} /{ }^{127} \mathrm{I}$ ratio is 
normally measured, and the ${ }^{129} \mathrm{I}$ absolute concentration is calculated by the ${ }^{127} \mathrm{I}$ content in the samples. For the samples with a ${ }^{129} \mathrm{I} /{ }^{127} \mathrm{I}$ ratio higher than $10^{-10}$, a large amount of ${ }^{127} \mathrm{I}$ carrier $(1-2$ $\mathrm{mg})$ comparing to the ${ }^{127} \mathrm{I}$ content in the sample itself $(<10 \mu \mathrm{g})$ is normally added to the sample before chemical separation, the ${ }^{129} \mathrm{I}$ concentration is then calculated by the ${ }^{127} \mathrm{I}$ added and the measured ${ }^{129} \mathrm{I} /{ }^{127} \mathrm{I}$ ratio. While for the sample with a low ${ }^{129} \mathrm{I} /{ }^{127} \mathrm{I}$ ratio $\left(<10^{-13}-10^{-10}\right.$, pre-nuclear age sample or less contaminated by human nuclear activity such as deep sea water, soil or sediment from deep layer), a carrier free iodine needs to be separated because of interference of ${ }^{129} \mathrm{I}$ in the ${ }^{127} \mathrm{I}$ carrier $\left(10^{-13}\right.$ for ${ }^{129} \mathrm{I} /{ }^{127} \mathrm{I}$ ratio for low background iodine carrier, such as iodine supplied by Woodward Iodine Corp. USA). For the high iodine concentration samples, such as brine, seaweed and thyroid, the carrier free ${ }^{129} \mathrm{I}$ may be easily separated, but for low iodine concentration sample, such as fresh water, terrestrial plant and animal sample $(<5 \mathrm{ng} / \mathrm{ml}$ water or $1 \mu \mathrm{g} / \mathrm{g}$ plant or animal sample), it is difficult to separate enough amount of carrier free iodine (150 $\mu \mathrm{g})$ [129]. Yiou et al [130] reported a method for prepare carrier free iodine from seawater. In this method, silver power is first added to the water, iodine species is then adjust to molecular iodine $\left(\mathrm{I}^{2}\right)$ and the water is stirred for 10-20 hours, Iodine is consequently absorbed on silver power and separated from the seawater. The method is very simple to operate and very useful for the separation of inorganic iodine from the seawater without carrier added. However, the volume of the sample is small (100$250 \mathrm{ml}$ ), it is therefore not sufficiency for the analysis of low level ${ }^{129}$ I sample, which needs a large sample. In addition, the recovery of iodine is also lower $(<50 \%)$.

\subsection{Inductively coupled plasma mass spectrometry (ICP-MS)}

ICP-MS has also been used for the determination of ${ }^{129} \mathrm{I}$ [131-136]. In this method, iodine separated from the samples is introduced to the machine as solution or gaseous iodine $\left(\mathrm{I}_{2}\right)$. The separation method used in NAA (section 4.3) can be also used for the separation of iodine from the samples.

In ICP-MS, iodine introduced to the plasma is decomposed into iodine atom and ionized to positive iodine ion at a temperature of approximately $6000-8000 \mathrm{~K}$. Due to higher ionization potential $(10.45 \mathrm{eV})$, ionization efficiency of iodine is normally lower comparing to metals, which results in a lower analytical sensitivity of iodine. The positively charged iodine is extracted from the plasma (at atmospheric pressure) into a high vacuum of the mass spectrometer via an interface. The extracted ions are then separated by mass filters of either quadrupole type time of flight or combination of magnetic and electrostatic sector, and finally measured by an ion detector. 
Problems associated to the determination of ${ }^{129} \mathrm{I}$ using ICP-MS is low sensitivity (low ionization efficiency), isobaric and molecular ions interferences $\left({ }^{129} \mathrm{Xe},{ }^{127} \mathrm{IH}_{2},{ }^{89} \mathrm{Y}^{40} \mathrm{Ar},{ }^{115} \mathrm{In}^{14} \mathrm{~N}\right.$, ${ }^{113} \mathrm{Cd}^{16} \mathrm{O}$ ), memory effects, low abundance sensitivity of ICP-MS (tailing from the ${ }^{127} \mathrm{I}$ peak), especially isobaric ${ }^{129} \mathrm{Xe}$ interference and tailing of ${ }^{127}$ I. A dynamic reaction cell (DRC) ICP-MS by using oxygen as reaction gas has been found to significantly reduce signals of xenon ions by charge transfer. It was also found that pressurizing the collision cell with helium the tailing of ${ }^{127} \mathrm{I}$ or abundance sensitivity can be improved. By using helium and oxygen in the DRC, and directly introducing gaseous iodine to the ICP-MS system, the detection limit of ICP-MS could be significantly improved to $10^{-6}$ for ${ }^{129} \mathrm{I} /{ }^{127} \mathrm{I}$ ratio (or $25 \mu \mathrm{Bq} / \mathrm{g}$ for ${ }^{129} \mathrm{I}$ at a ${ }^{127} \mathrm{I}$ concentration of $4 \mu \mathrm{g} / \mathrm{g}$ ) [134]. By trapping gaseous iodine thermally released from samples, and then desorbing it into the ICP-MS system, detection limit could be further improved to $2.5 \mu \mathrm{Bq} / \mathrm{g}$ (or $10^{-7}$ for ${ }^{129} \mathrm{I} /{ }^{127} \mathrm{I}$ ratio) [135]. By using a similar techniques, but directly introducing water samples in $1 \%$ tertiary amine carrier solution, a detection limit of $37 \mu \mathrm{Bq} / \mathrm{ml}$ was reported [136].

Table 3 compares various analytical methods for the determination of ${ }^{129} \mathrm{I}$. The $\gamma$ spectrometry and LSC are the least sensitive and long counting time, while they are cheaper and good accessible. These methods are therefore only suitable for the analysis of nuclear waste and high level environmental samples $\left({ }^{129} \mathrm{I} /{ }^{127} \mathrm{I}\right.$ higher than $\left.10^{-6}\right)$. By using DRC techniques, ICP-MS can be used for the determination of ${ }^{129} \mathrm{I}$, but the detection limit for ${ }^{129} \mathrm{I} /{ }^{127} \mathrm{I}$ is only $10^{-7}$, it may only be suitable for the analysis of high level environmental samples. Only NAA and AMS are sensitive enough for the analysis of environmental samples $\left({ }^{129} \mathrm{I} /{ }^{127} \mathrm{I}\right.$ ratio higher than $\left.10^{-10}\right)$. In which AMS is the only method for analysis of per-nuclear age samples with ${ }^{129} \mathrm{I} /{ }^{127} \mathrm{I}$ ratio lower than $10^{-10}$.

\section{Speciation analysis of ${ }^{129} I$ in environment and its application}

In principle, method for speciation analysis of ${ }^{129} \mathrm{I}$ in the environment should be the same as for stable iodine considering the natural sources and assuming isotopic equilibrium. However, as described above, the naturally occurred ${ }^{129} \mathrm{I}$ (generated from the uranium fission and cosmic ray reaction of $\mathrm{Xe}$ ) is overwhelmed by the anthropogenic ${ }^{129} \mathrm{I}$ from the human nuclear activity since 1945, especially the release from the reprocessing plants since 1990's. This situation has created isotopic disequilibrium between ${ }^{127} \mathrm{I}$ and ${ }^{129} \mathrm{I}$ in the environment, which may partly result from a different distribution of ${ }^{129}$ I species compared to stable iodine $\left({ }^{127} \mathrm{I}\right)$. Although there are a number of reports on the speciation analysis of stable iodine, data on ${ }^{129} \mathrm{I}$ speciation is still scarce. The 
extremely low concentration of ${ }^{129} \mathrm{I}$ in the environment compared to stable ${ }^{127} \mathrm{I}\left({ }^{129} \mathrm{I} /{ }^{127} \mathrm{I}\right.$ lower than $10^{-6}$ ) requires a large sample for the analysis of ${ }^{129} \mathrm{I}$ species, which makes application of the conventional method used for speciation analysis of stable iodine unpractical for ${ }^{129} \mathrm{I}$. New separation procedures have to be developed for ${ }^{129} \mathrm{I}$ speciation analysis, which is reviewed below with comments on their potential and applications.

\subsection{Speciation of ${ }^{129} I$ in water}

In seawater, iodine exists mainly as iodide and iodate with a minor organic iodine and consequently speciation analysis of iodine in seawater commonly focus on iodide and iodate. Hou et al. [23] has developed a chemical procedure for the separation of iodide and iodate from large seawater samples (up to 50 liters). The method is based on different affinities of iodide, iodate and other anions, such as $\mathrm{Cl}^{-}$and $\mathrm{Br}^{-}$, on anion exchange column. Iodide with a strong affinity is absorbed on the column, while iodate with a low affinity pass through the column or very weekly adsorbed on the column with $\mathrm{Br}^{-}$and $\mathrm{Cl}^{-}$. These anions can easily be removed from the column by using low concentration of nitrate $(<0.5 \mathrm{~mol} / \mathrm{l})$. The adsorbed iodide on the column is eluted using high concentration of nitrate $(1.5-2.0 \mathrm{~mol} / \mathrm{l})$. Converting the anion exchange resin to nitrate form instead of chloride form enhances the capacity of the anion exchange column for iodide by 5-10 times, which is a useful approach for analysis of large seawater sample. The iodate in the effluent and wash (with $\mathrm{Br}^{-}$and $\mathrm{Cl}^{-}$) is then converted to iodide by addition of $\mathrm{NaHSO}_{3}$ and acidifying to pH2-3 using HCl. The solution is then passed through another anion exchange column, where the iodide absorbed on the column is eluted using $2.0 \mathrm{~mol} / 1 \mathrm{NaNO}_{3}$ for the determination of iodate. The iodide in nitrate eluate is then concentrated using $\mathrm{CCl}_{4}$ or $\mathrm{CHCl}_{3}$ extraction following the same procedure for extraction of total ${ }^{129} \mathrm{I}$ (section 4.3). The separated ${ }^{129} \mathrm{I}$ in iodide and iodate is then measured using NAA or AMS [13, 23]. A schematic flow chart of the analytical procedure is shown in Fig. 6. However, organic ${ }^{129} \mathrm{I}$ cannot be determined in this procedure. Schwehr et al. [17] proposed a procedure for the determination of organic ${ }^{129} \mathrm{I}$ where water sample is first digested by heating under ultrasonic condition in $\mathrm{NaOH}$ and ethanol medium. This step is supposed to decompose all organic matters and iodine in organic form would be released and converted to inorganic iodine. Later an anion exchange chromatography and $\mathrm{CCl}_{4}$ extraction are used to extract total ${ }^{129} \mathrm{I}$. The organic ${ }^{129} \mathrm{I}$ in the sample is then calculated by the difference between total ${ }^{129} \mathrm{I}$ and the sum of ${ }^{129} \mathrm{I}^{-}$and ${ }^{129} \mathrm{IO}_{3}^{-}$. For water from estuaries, rivers and lakes, the concentration of organic 
${ }^{129}$ I may be significant comparing to iodide and iodate for which the procedure described above can be also used.

Anion exchange chromatography is a good method for the separation of iodide and iodate, and has been successfully applied for the analysis of seawater and fresh water in the laboratory. However, the procedure is time consuming and not practically suitable for treatment of water samples in the field and on board sampling vessels. It is recommended that speciation analysis, especially the separation part, to be carried out during a short time after the sampling. In addition in situ separation can meet the requirement of analysis of large number of samples without a problem of transport (shipping, etc) to get the samples back to the laboratory. Accordingly, a new and simple speciation method has been developed using $\mathrm{AgCl}$ co-precipitation for the speciation analysis of ${ }^{129} \mathrm{I}$ in seawater. In this method, ${ }^{125} \mathrm{I}^{-}$tracer and ${ }^{127} \mathrm{I}^{-}$carrier are first added to the seawater and the $\mathrm{pH}$ of sample is adjusted to 4-6 using $\mathrm{HCl}$. $\mathrm{AgNO}_{3}$ is added with a ratio of $\mathrm{Ag}: \mathrm{Cl}$ less than 100, and $\mathrm{Ag:I}$ higher than 5. After stirring for 0.5-1 hour, $\mathrm{AgI}$ precipitated with $\mathrm{AgCl}$ is then separated by decanting the supernatant after settling down and centrifuging. The AgI is afterwards separated from $\mathrm{AgCl}$ by addition of $\mathrm{NH}_{3}$ to dissolve $\mathrm{AgCl}$, and centrifuge. The separated $\mathrm{AgI}$ is used for AMS measurement of ${ }^{129} \mathrm{I}^{-}$after dryness [134]. For the determination of total inorganic ${ }^{129} \mathrm{I}$, the sample is acidified to $\mathrm{pH} 2$ after addition of $\mathrm{NaHSO}_{3}$ and the iodate, which was converted to iodide, is then separated with iodide using the same method as for ${ }^{129} \mathrm{I}^{-}$. The concentration of ${ }^{129} \mathrm{IO}_{3}{ }^{-}$is calculated by the difference between total inorganic ${ }^{129} \mathrm{I}$ and ${ }^{129} \mathrm{I}^{-}$. The ${ }^{125} \mathrm{I}$ tracer experiment showed that the recovery of iodine in this method is higher than $85 \%$, and cross contamination of ${ }^{129} \mathrm{I}^{-}$and ${ }^{129} \mathrm{IO}_{3}{ }^{-}$is less than $2 \%$ [137]. This separation method is suitable for the in situ work in the field or on board of a ship.

${ }^{129}$ I discharged from reprocessing plants in La Hague and Sellafield has been used as a specific source of ${ }^{129} \mathrm{I}$ in the Nordic seawater. The signal of ${ }^{129} \mathrm{I}$ is used as a tracer to investigate marine geochemical cycle of stable iodine and in particular for conversion mechanisms of different chemical species of iodine as well as distinguishing newly produced from converted iodine species. Hou et al. $[15,23]$ have measured iodide and iodate in seawater collected from the English Channel, North Sea, as well as Kattegat and Baltic Sea. The ratios of iodide/iodate for ${ }^{129} \mathrm{I}$ and ${ }^{127} \mathrm{I}$ in these waters are shown in Fig. 7, which indicates significantly different speciation distribution for ${ }^{129}$ I and stable iodine $\left({ }^{127}\right.$ I). It was concluded that; 1) a rapid reduction of iodate to iodide occurs along the European continental coastal area, 2) oxidation of the new produced iodide to iodate does not occur during its transit along the European continental coast and 3) reduction of iodate or oxidation of 
iodide in the open sea seems to be a slow process [15]. The ratio of ${ }^{129} \mathrm{I} /{ }^{127} \mathrm{I}$ for iodate in the Baltic seawater is much higher than that for iodide and close to the level in the Kattegat. This result suggests that ${ }^{129} \mathrm{I}$ in the iodate form in Baltic Sea water seems originated from the Kattegat, and implies a slow reduction process of iodate in the Baltic Sea.

River flood can also provide ${ }^{129} \mathrm{I}$ in the estuary areas as observed by speciation analysis of ${ }^{129} \mathrm{I}$ and ${ }^{127} \mathrm{I}$ in Galveston Bay, Texas USA [17]. Organic ${ }^{129} \mathrm{I}$ from the terrestrial source was observed in water with salinity up to about 20 within the Bay area, which agrees with the observation from stable isotopes, such as ${ }^{13} \mathrm{C}$ and ${ }^{14} \mathrm{~N}$, and suggested that organic ${ }^{129} \mathrm{I}$ can be used as a tracer for the dissolved organic carbon in coastal zones.

\subsection{Speciation of ${ }^{129} I$ in atmosphere}

As mentioned above, iodine in the atmosphere exists as particle associated, inorganic gaseous iodine (such as $\mathrm{I}_{2}, \mathrm{HI}, \mathrm{HIO}$ ) and organic iodine $\left(\mathrm{CH}_{3} \mathrm{I}, \mathrm{CH}_{2} \mathrm{I}_{2}, \mathrm{CH}_{3} \mathrm{CH}_{2} \mathrm{CH}_{2} \mathrm{I}\right.$, etc.). Due to very low concentration of ${ }^{129} \mathrm{I}$ in the atmosphere, the determination of individual species of ${ }^{129} \mathrm{I}$ is difficult. The speciation analysis of ${ }^{129} \mathrm{I}$ is mainly focused on the determination of three fractions of ${ }^{129} \mathrm{I}$ (particle associated, inorganic and organic gaseous ${ }^{129} \mathrm{I}$ ) $[20,138]$, as well as the distribution of ${ }^{129} \mathrm{I}$ in different size of particulates [139]. The main technique used for collection of three fractions of ${ }^{129} \mathrm{I}$ is illustrated in Fig. 8 (Hou, unpublished). The sampler consists of multistage collector/trapper which is finally connected to a vacuum pump. Particle associated iodine is first collected by a membrane with small size pore $(<0.45 \mu \mathrm{m})$, the gaseous iodine pass through the membrane, of which inorganic species, such as $\mathrm{I}_{2}$ and $\mathrm{HI}$, is then trapped by cellulous filter papers previously impregnated with $\mathrm{NaOH} /$ glycerin. For completely trapping of the inorganic gaseous iodine, two cascade filter papers are used. Following the filter papers, an active charcoal column with length of $2.5 \mathrm{~cm}$ is used for trapping organic gas iodine. To obtain a sufficient trapping efficiency, the active charcoal was previously impregnated with tetrabutylammoniumhydroxide (TBAH) or triethylenediamine (TEDA) solution. Experiments have shown a satisfactory separation of three fractions of iodine [70-71]. Iodine in the collected fractions is then separated by combustion using a tube oven (Fig. 5), and trapped in $\mathrm{NaOH}$ solution, then extracted using $\mathrm{CCl}_{4}$ or $\mathrm{CHCl}_{3}$ and prepared as $\mathrm{MgI}_{2}$ or $\mathrm{AgI}$ for measurement. Besides ${ }^{129} \mathrm{I}$, stable iodine in the atmosphere is normally also required in order to obtain the ${ }^{129} \mathrm{I} /{ }^{127} \mathrm{I}$ value, which is more useful instead of only ${ }^{129} \mathrm{I}$ concentration. In this case, the stable iodine blank in collecting materials, such as filters, active charcoal, TBAH and/or TEDA is very important. A low iodine blank charcoal and chemical reagent have to be 
chosen. A low iodine content TEDA (Sigma, Germany) with iodine concentration of $6.5 \mathrm{ng} \mathrm{g}^{-1}$ was used in the author's laboratory, comparing to a similar reagent of TBAH $(20 \%$ solution in water for synthesis, Merck, Germany) with an iodine concentration of $164 \mathrm{ng} \mathrm{mL}^{-1}$. In addition, for reducing iodine blank in active charcoal, $\mathrm{NaOH}$ solution leaching and heating at high temperature (900$1000^{\circ} \mathrm{C}$ ) under nitrogen condition have been used [71], however, our experiment showed that only less than half of iodine in the charcoal can be removed by these methods. It is therefore better to find a low iodine blank charcoal. A low iodine content active charcoal (for chromatography, Merck, Germany) was used in the author's laboratory, in this charcoal, the total iodine concentration of only $40 \mathrm{ng} \mathrm{g}^{-1}$ was measured, after washing with $\mathrm{NaOH}$ solution, the iodine concentration was reduced to $30 \mathrm{ng} \mathrm{g}^{-1}$. The concentration of iodine in TEDA impregnated charcoal was measured to be only $45 \mathrm{ng} \mathrm{g}^{-1}$, which is more than 30 times lower than the commercial TEDA impregnated charcoal specific designed for trapping radioactive iodine (TEDA Carbon Cartridge, The Staplex Company, Brooklyn, USA), we have measured iodine concentration in this charcoal to be $1400 \mathrm{ng}$ $\mathrm{g}^{-1}$.

Several investigations have been carried out to measure different species of ${ }^{129} \mathrm{I}$ in atmosphere. Wershofen \& Aumann [20] have measured ${ }^{129} \mathrm{I}$ and ${ }^{127} \mathrm{I}$ in three fractions in the atmosphere collected from locations with varying distance $(0-23 \mathrm{~km})$ to the WAK reprocessing plant in Germany. They observed a different distribution of ${ }^{129} \mathrm{I}$ and ${ }^{127} \mathrm{I}$ in these three fractions. Particle associated ${ }^{129} \mathrm{I}$ ranges at $2-30 \%$ of total ${ }^{129} \mathrm{I}$, while the corresponding ${ }^{127} \mathrm{I}$ ranges at $12-28 \%$ of total iodine. The gaseous inorganic ${ }^{129} \mathrm{I}$ fraction ranges at $17-35 \%$ while the ${ }^{127} \mathrm{I}$ is $1.5-27 \%$. Similarly large variation is found between gaseous organic ${ }^{129} \mathrm{I}\left(34-98 \%\right.$ of total $\left.{ }^{129} \mathrm{I}\right)$, and ${ }^{127} \mathrm{I}$ (46$74 \%$ of total iodine). It was also noticed that the closer the location to the reprocessing plant, the higher the percentage of gaseous organic ${ }^{129} \mathrm{I}$, while no such a trend was observed for ${ }^{127} \mathrm{I}$. This feature indicates that equilibrium between ${ }^{129} \mathrm{I}$ and ${ }^{127} \mathrm{I}$ in the atmosphere takes long time due to different sources and species. ${ }^{129} \mathrm{I}$ species in the atmosphere near the Sellafield reprocessing plant (1.3 km northern northwest) was also measured. It was found that $63-100 \%$ of ${ }^{129} \mathrm{I}$ was organic gaseous ${ }^{129} \mathrm{I}$, while inorganic gaseous and particle associated ${ }^{129} \mathrm{I}$ compose less than $21 \%$ and $17 \%$ respectively (Z. Ferozan, personal communication). Although direct measurement of ${ }^{129}$ I species in the atmosphere from the stack in reprocessing plants is not available, it was estimated that in one stack in Sellafield reprocessing plant, 70\% iodine was released as inorganic ${ }^{129} \mathrm{I}\left(\right.$ mostly $\mathrm{I}_{2}$ ) and $30 \%$ of organic ${ }^{129} \mathrm{I}$. In another stack in the same reprocessing plant, $100 \%{ }^{129} \mathrm{I}$ is released as organic ${ }^{129} \mathrm{I}$ 
(Z. Ferozan, personal communication). However, the measured ${ }^{129} \mathrm{I}$ in the environment was mainly organic gaseous ${ }^{129}$ I [20, Z. Ferozan, personal communication].

Comparing to ${ }^{129}$ I released to the atmosphere from the stacks in reprocessing plants, a large amount of ${ }^{129} \mathrm{I}$ has being discharged to the English Channel from La Hague reprocessing plant and to the Irish Sea from Sellafield reprocessing plant (Fig. 2). It is well known that iodine in the ocean is emitted to the atmosphere as methyl iodide and other gaseous forms, which may contribute to the ${ }^{129} \mathrm{I}$ load in the atmosphere. It has been accepted for a long time that iodine in the ocean is the main source of iodine on land [137]. However, recent data suggest that releases from the terrestrial pool, vegetation and soil can add significant amounts to the atmosphere [141-142]. It was also argued that comparable iodine deposition in the coastal and the inland areas suggests that iodine flux to soil from terrestrial plant release is comparable to those from the ocean [141-142]. One measurement of ${ }^{129}$ I species in atmosphere over the North Sea has been carried out indicating that particle associated, inorganic and organic gaseous ${ }^{129} \mathrm{I}$ were $18 \%, 43 \%$ and $40 \%$ respectively, with a similar distribution for ${ }^{127} \mathrm{I}$. The ${ }^{129} \mathrm{I} /{ }^{127} \mathrm{I}$ values in different fractions were significantly different with the highest value $\left(8.4 \times 10^{-7}\right)$ in particle, lowest value in inorganic gas fraction $\left(1.2 \times 10^{-7}\right)$ and $3.1 \times 10^{-7}$ in organic gas fraction [39]. This indicates different sources of ${ }^{129} \mathrm{I}$ and ${ }^{127} \mathrm{I}$ in the atmosphere and also shows that ${ }^{129} \mathrm{I}$ can be used as a potential tracer for the geochemical cycle of stable iodine such as transfer of iodine from ocean to atmosphere, soil, plant and humans.

During the Chernobyl accident, a large amount of radioactivity was released to the atmosphere, including ${ }^{129} \mathrm{I},{ }^{131} \mathrm{I}$, and other iodine radioisotopes. Unfortunately, data on ${ }^{129} \mathrm{I}$ speciation in the source plume from the accident is not available, but it was supposed that most of ${ }^{129} \mathrm{I}$ and ${ }^{131}$ I have been released as $\mathrm{I}_{2}$. Measurements carried out in Lithuanian and Japan for speciation of ${ }^{129} \mathrm{I}$ and ${ }^{131} \mathrm{I}$ during the Chernobyl accident $[70,138]$ indicated that $60-80 \%$ was observed in organic gaseous form, whereas the inorganic gas composes less than $10 \%$, and the particle associated form is less than $35 \%$. The high fraction of organic form of ${ }^{129} \mathrm{I}$ and ${ }^{131} \mathrm{I}$ may be attributed to conversion during long distance (longer time) transport of the radioactive plume.

The availability of radionuclides in the atmosphere is not only related to their species, but also to the size of the particles. The size distributions of ${ }^{129} \mathrm{I}$ and ${ }^{131} \mathrm{I}$ associated particles in the atmosphere have been investigated using cascade impactor air sampler [143-145]. It was observed that ${ }^{129} \mathrm{I}$ and ${ }^{131} \mathrm{I}$ are mainly associated with fine particles, with a ${ }^{129} \mathrm{I}$ activity median aerodynamic diameter $(\mathrm{AmAD})$ of $0.4 \mu \mathrm{M}$ [143]. A similar distribution pattern was also observed for ${ }^{131} \mathrm{I}$ originated from the Chernobyl accident (with an AmAD of 0.2-0.4 $\mu \mathrm{m}$ ) [144-145]. 


\section{$5.3{ }^{129}$ I speciation in soil and sediment}

Direct measurement of iodine speciation in soil and sediment is normally difficult, but techniques such as X-ray absorption near-edge structure (XANES) and extended X-ray absorption fine structure spectra (EXAFS) have been utilized. The relatively low concentration of ${ }^{129} \mathrm{I}$ in the environment and the low sensitivity of XANES and EXAFS make direct measurement of ${ }^{129}$ I even more difficult. Therefore, sequential extraction or selective extraction is normally applied for separation of different components (speciation) of soil and sediment. A sequential extraction procedure that was proposed by Tessier et al. [146] has found wide applications. In this method the iodine was separated as water soluble, exchangeable, carbonate, metal oxides (reducible), organic bound, and residue (mineral bound). Because iodine is easily volatile in acidic and oxidizing condition, modification of the original procedure has to be performed in order to avoid iodine loss during the extraction.

For the sequential extraction separation, the batch method is normally applied for easy operation and apparatus requirement. However, this method is time consuming, steady state leaching process and is associated with risk of cross contamination and re-adsorption. To over come these shortages, a dynamically method was therefore proposed for sequential extraction of some radionuclides [147], and has been applied for iodine fractionation/speciation in soil and sediment samples in the authors' lab.

In the batch sequential extraction procedure, the water-soluble iodine is first extracted using water and the leachate is separated by centrifuge. Remained solid is then treated with $\mathrm{CaCl}_{2}, \mathrm{MgCl}_{2}$ or $\mathrm{NH}_{4} \mathrm{OAc}$ solution ( $\mathrm{pH} 7-8$ ) to recover exchangeable fraction. Remained residue from this treatment is extracted again using $\mathrm{NH}_{4} \mathrm{OAc}$, but at $\mathrm{pH} 5$ for carbonate. All these steps are operated at room temperature. Afterward, the oxyhydroxides (or reducible) fraction is extracted using $\mathrm{NH}_{2} \mathrm{OH} \cdot \mathrm{HCl}-\mathrm{HOAc}$ at $\mathrm{pH} 2$ and the remained sample is finally extracted for organic fraction using $\mathrm{H}_{2} \mathrm{O}_{2}-\mathrm{HNO}_{3}$ at $\mathrm{pH} 2$ or $\mathrm{NaOH}$ or $\mathrm{NH}_{2} \mathrm{OH} \cdot \mathrm{HCl}$-carbonate (pH8-9). These two steps are carried out at $80-100^{\circ} \mathrm{C}$. The remained fraction is treated as a residue. A schematic diagram of the whole procedure is shown in Fig. 9. Use of $\mathrm{H}_{2} \mathrm{O}_{2}-\mathrm{HNO}_{3}$ for the extraction of organic fraction means that the iodine will be oxidized to $\mathrm{I}_{2}$ and lost during the extraction. Therefore a use of $\mathrm{NaOH}(0.3 \mathrm{~mol} / \mathrm{l})$ or $\mathrm{NH}_{2} \mathrm{OH} \cdot \mathrm{HCl}-\mathrm{Carbonate}$ is a recommended alternative method for extraction of iodine in organic fraction [21, 77]. To completely destroying organic substances, treatment with $\mathrm{NaClO}$ decomposition is followed after the $\mathrm{NaOH}$ or $\mathrm{NH}_{2} \mathrm{OH} \cdot \mathrm{HCl}-\mathrm{Carbonate}$ extraction [148]. Another 
approach is to extract the organic fraction using $\mathrm{H}_{2} \mathrm{O}_{2}-\mathrm{HNO}_{3}$, but both residues (before and after the extraction) are analyzed for iodine and the difference in iodine content of these two samples is calculated as the organic fraction [36].

For soil or sediment with high organic matter content, the order of sequential extraction may be partly modified due to the wrapping of grains by organic matters that may reduce the extraction efficiency during the different steps, especially for the oxides fraction step. Additionally, the released iodine from the sample may be easily re-adsorbed to organic matters during oxidizing and acid condition. For this purpose, iodine associated to organic fraction may be extracted before the oxides fraction and after the carbonate fraction using $\mathrm{NaOH}$ or $\mathrm{NaOCl}$. In this case, oxides component can be decomposed and iodine binding to this component can be completely released.

${ }^{129} \mathrm{I}$ in the separated fractions is then further purified by $\mathrm{CCl}_{4}$ (or $\mathrm{CHCl}_{3}$ ) extraction after conversion of all iodine to iodide form. For the organic fraction, if $\mathrm{NH}_{2} \mathrm{OH} \cdot \mathrm{HCl}$-Carbonate or $\mathrm{NaOH}$ method is used, a further decomposition using $\mathrm{NaOCl}$ may be needed before the $\mathrm{CCl}_{4}$ extraction. ${ }^{129} \mathrm{I}$ in the final residue can be separated using the same method as that for total ${ }^{129} \mathrm{I}$ in soil and sediment sample, i.e. combustion or alkali fusion, described in the section 4.3.

Schmitz \& Aumann [21] have analyzed soils collected from a region closed to the WAK reprocessing plant in Germany and found a relatively higher percentage of ${ }^{129} \mathrm{I}$ in water soluble (39$49 \%$ ), exchangeable (7-20\%), and residue (25-70\%) fractions compared to the organic (4-15\%), oxides (7-13\%) and carbonate (3-8\%) fractions. However, a different distribution of stable iodine $\left({ }^{127} \mathrm{I}\right)$ was observed where only $<4 \%$ occurs in the water soluble fraction. This difference between ${ }^{129} \mathrm{I}$ and stable iodine may be attributed to the different sources of the two isotopes. ${ }^{129}$ I has mainly short period anthropogenic sources, while ${ }^{127} \mathrm{I}$ has both natural and anthropogenic sources and resided in the soil for a relatively long time. This implies that chemical equilibrium between ${ }^{129}$ I and stable ${ }^{127}$ I within the soil environment may take a long time and resulting in different speciation patterns with respect to mobility and bioavailability of the two isotopes. Apparently, this result shows that ${ }^{129} \mathrm{I}$ in the soil is more mobile and bio-available than ${ }^{127} \mathrm{I}$.

Another distribution pattern of ${ }^{129} \mathrm{I}$ is observed in the soil and sediment collected from coastal and estuarine area around the Sellafield reprocessing plant [76] compared to that observed in the soil from near the WAK reprocessing plant [21]. Higher percentage of ${ }^{129}$ I was found in oxides (53$66 \%$ ) and organic (23-43\%) fractions, whereas only $<7.5 \%$ was found in the other fractions (the residue was not included). A similar result was also obtained from soil sample $(2-4 \mathrm{~cm}$ depth) collected from the Chernobyl accident contaminated area (10 $\mathrm{km}$ to Chernobyl power plant) and in 
sediment from the Irish Sea. In both materials, ${ }^{129} \mathrm{I}$ in the oxides (30-40\%) and organic (40-48\%) fractions is higher than in the water-soluble fraction (6-13\%) [22]. Results from sediment samples (organic content $>50 \%$ ) collected from a lake (in central Sweden) showed that most ${ }^{129}$ I is mainly bound to the organic fraction (50-85\%), whereas the water soluble, exchangeable and carbonate fraction contain $5-8 \%$, but relatively higher than ${ }^{127} \mathrm{I}(2-4 \%)$. The oxides-related fraction contains $<$ $2 \%$ of ${ }^{129} \mathrm{I}$ and ${ }^{127} \mathrm{I}$ respective total content [148]. The different distribution of ${ }^{129} \mathrm{I}$ in the near source area materials (Chernobyl, Sellafield and WAK) compared with far from source materials (central Sweden) may relate to conversion of ${ }^{129}$ I species upon transport as well as environmental conditions at the sampling site.

Besides fractionation, the chemical speciation of iodine in leachate, especially in water soluble and exchangeable fraction can be carried out to investigate the chemical forms of iodine in soil and sediment sample. The method used for the speciation of iodine in water sample can be used for this purpose. Yuita [78] has investigated the chemical speciation of stable iodine in soil solution (water soluble), high iodide percentage was observed in flood and anoxic condition, while iodate is the dominate species in non-flood and oxidizing condition. Data on the ${ }^{129}$ I speciation in soil solution are still lacking. .

The direct measurement of in situ iodine speciation, especially in solid sample, is performed using XANES and EXAFS, which can be used to provide information on the local structure, coordination number and oxidation state of a range of elements in solution, solid form or at a solution-solid interface [148-150]. Using XANES a high intensity monochromatic X-ray beam (usually provided by a synchrotron source) is tuned through a range of energies from a few tens of $\mathrm{eV}$ below to about $100 \mathrm{eV}$ above the binding energy of a core electron (e.g. iodine K-edge 33.17 $\mathrm{keV}$ and Iodine $\mathrm{L}_{3}$-edge $4.557 \mathrm{keV}$ ) while keeping the beam on the same spot on the sample. The attenuation of the X-rays varies smoothly with incident energy until a critical energy is reached (i.e. core electron binding energy) and absorption (and fluorescence) abruptly increases. This discontinuity corresponds to the ejection of a core electron from an atom and is called the absorption edge, while the main absorption feature is referred to as the white line. The energy position of the white line is characteristic of the excited atom. The fine structure and position of the absorption edge can reveal information on the oxidation state of the element and its chemical surrounding (Fig. 10). This can readily be utilized as a "fingerprinting" technique by comparing reference samples with unknown samples [100]. Further speciation information can be obtained at the same time by extending the energy range $(\sim 50 \mathrm{eV}-1000 \mathrm{eV}$ above absorption edge $)$ over 
which the data are collected, i.e. extended X-ray absorption fine structure (EXAFS) (The entire structured absorption region (XANES+EXAFS) is also referred to as XAFS). EXAFS can give additional information on the coordination numbers and bond lengths to first, second and even more distant neighbor atoms [151]. However, EXAFS works best for ideal systems and information on the local structure is often needed before beginning an analysis [152].

Shimamoto and Takahashi [153] found that despite iodine K-edge XANES profiles are relatively featureless compared to those of $\mathrm{L}_{\mathrm{III}} \mathrm{XANES}$, analysis of soil with iodine concentrations of $55 \mu \mathrm{g} / \mathrm{g}$ and high Ca concentrations in particular, should preferably be carried out at the K-edge because of the lower detection limit (avoiding the interference of Ca K X-rays with I L $\alpha$ ). They identified that the iodine in the soil is mainly as organic form. However, the detection limit of XANES is too high $\left(>10 \mu \mathrm{g} / \mathrm{g}\right.$ or $>70 \mathrm{~Bq} / \mathrm{g}$ for $\left.{ }^{129} \mathrm{I}\right)$ to measure ${ }^{129} \mathrm{I}$ in environmental samples. Reed et al. [100] utilized iodine K-edge XANES in an attempt to identify the speciation of 10-100 ppm concentrations of ${ }^{129} \mathrm{I}(70-700 \mathrm{~Bq} / \mathrm{g})$ in nuclear waste reprocessing solvent (tri-n-butyl phosphate in odourless kerosene (TBP/OK)) from Sellafield reprocessing plant. The XANES profile of the waste sample resembled those of organoiodide reference samples. However, the presence of some molecular iodine could not be excluded due to the similarities between organoiodide and $\mathrm{I}_{2}$ XANES spectra and poor statistics related to low concentrations. Other inorganic species of iodine appears to be relatively easy to deduce from organic species because they tend to have more structure in the post-edge region [100]. Employing I LIII XANES and EXAFS, Schlegel et al. [154] were able to show that iodine in naturally iodinated humic substances is aromatic-bound. XANES and EXAFS are qualitative analytical techniques, which means that information on distribution of different species of elements or radionuclides could not be supplied. Artifacts in XANES experiments due to radiation damage have been reported for several types of samples [155] and elements including iodine [153]. To monitor possible beam damage, energy scans repeated several times for each position of interest may be compared.

\section{$5.4{ }^{129}$ I speciation in biological samples}

A large number of investigations have been carried out on the speciation of stable iodine, and on the determination of total ${ }^{129} \mathrm{I}$ in biological samples including seaweed, grass, and thyroid. However, to our knowledge, published data on the speciation of ${ }^{129} \mathrm{I}$ in biological samples are not available. The separation of different species of stable iodine in biological samples, such as blood, milk, urine, homogenate of tissues and extractions of plants is normally carried out by high 
performance liquid chromatography (HPLC), electrophoresis, and gel chromatography [57-60, 62, 156-158]. These methods are suitable for the species separation of stable iodine in biological samples, especially for organic species of iodine. However, the size of sample applied for the analysis is normally small $(<1 \mathrm{ml})$, which is not suitable for ${ }^{129} \mathrm{I}$ due to minute concentration compared to stable iodine in biological samples $\left({ }^{129} \mathrm{I} /{ }^{127} \mathrm{I}<10^{-6}\right)$.

The speciation analysis of ${ }^{129} \mathrm{I}$ normally needs a large amount samples $(>5 \mathrm{~g})$ and the separation methods developed by Hou et al [42-43, 57] for seaweed and tissues are suitable for the speciation of ${ }^{129}$ I. For tissue samples, various sub-cellular fractions of tissue are separated using gradient centrifugation, these fractions include nuclei, cytrosol, mitochondria, lysosome, and microsome. The iodine-bound proteins in cytosol of tissue are separated using gel-chromatography (exclusion chromatography) for different molecular size. For the speciation analysis of ${ }^{129} \mathrm{I}$ in seaweed, various fractions such as water-soluble iodine, soluble organic iodine, iodide, iodate, and protein-, pigment- polyphenol- or polysaccharide-bound iodine can be separated using the method developed by Hou et al. [42-43]. The soluble iodine was first separated from the seaweed by water leaching, iodide, iodate, and organic iodine in the leachate can be then separated by using the anion exchange method as that used for water samples (Fig.4] [23]. To investigate combination of ${ }^{129}$ I in different components, such as protein, polyphonel, and pigment, several procedures can be used [43]. The separated organic binding ${ }^{129}$ I fractions needs to be decomposed to be converted into inorganic iodine, in which the ashing or combustion method described above can be used. The inorganic iodine is finally concentrated and purified by $\mathrm{CCl}_{4}$ extraction and precipitated as $\mathrm{AgI}$ for AMS measurement.

\section{Bioavailability and radiation toxicity of ${ }^{129} I$}

The bioavailability of an element in the environment depends on its species. For ${ }^{129} \mathrm{I}$, there are practically scattered or almost lack of data about this issue. The various values of transfer factor (concentration of element in plant divided by that in the soil it grows on) of ${ }^{129} \mathrm{I}$ from soil to the grass (from 0.07 to 2.9 dry/dry weight) may reflect the different species of ${ }^{129} \mathrm{I}$ in the soil [156]. It is expected that the water soluble and exchangeable ${ }^{129}$ I can easily be taken up by plants through root, while bound in other fractions, such as organic, oxides and minerals is more difficult to be taken up. However, uptake of iodine by leaves from atmosphere is also a main pathway of iodine in plants.

It was reported that the bioavailability of iodine through potassium iodide to human (or mammals) is $96.4 \%$, while the bioavailability of iodine through organic forms such as 
monoiodotyrosine is $80.0 \%$. A high bioavailability of iodine in seaweed Gracilaria verrucosa and Laminaria hyperborean (80-99\%) was also observed [160]. Jahreis et al. [161] investigated the luptake of iodine through diet in 12 women, and found that $89 \%$ of iodine was excreted in the urine, and $11 \%$ in the fasces. However, Wahl et al. [162] reported low uptake of iodine from normal diet where only $16 \%$ to $18 \%$ of the alimentary iodine was excreted in the urine. This may indicate that the type of diet and species of iodine in the foodstuff are factors affecting bioavailability of iodine to human. A relatively low water (or acid) leaching rate of iodine (28-40\%) from vegetable (spinach and green seaweed) was reported by Hou et al. [43].

Iodine in food is digested and absorbed in stomach and small intestine and passes into blood. Inhaled iodine from the air is also transferred into blood. Most of iodine absorbed into the blood is concentrated in the thyroid, and small part of iodine is directly excreted to the urine depending on the total amount of iodine in the diet. Most of iodine $(>80 \%)$ in the human body (or mammal) concentrated in the thyroid, which is therefore the target organ (to it a specific element or compound is concentrated) of iodine (including radioactive ${ }^{129} \mathrm{I}$ ). An average iodine content in adult thyroid is $10-15 \mathrm{mg}$, essentially combined with thyroglobulin, which is breakdown to the hormones triiodothyronine (T3) and thyroxine (T4) and released to the blood and transferred to other body tissues. The thyroid takes up stable and radioactive iodine indiscriminately. Due to low beta and gamma energy of ${ }^{129} \mathrm{I}$ (Table 1), radiation toxicity of ${ }^{129} \mathrm{I}$ is therefore mainly related to internal exposure of the thyroid to the beta radiation of ${ }^{129} \mathrm{I}$. However, long half-life of ${ }^{129} \mathrm{I}$ $\left(1.57 \times 10^{7}\right.$ years) means long-term and low dose exposure. ${ }^{129} \mathrm{I}$ concentration (or ${ }^{129} \mathrm{I} /{ }^{127} \mathrm{I}$ value) in thyroid can be supposed to be equilibrium with ${ }^{127} \mathrm{I}$ the diet. It was reported that the equilibrium dose rate of ${ }^{129} \mathrm{I}$ in the thyroid is $0.151 \mathrm{mSv} / \mathrm{Bq} / \mathrm{y}$ and $0.0161 \mathrm{mSv} / \mathrm{Bq} / \mathrm{y}$ for a one-year old child and an adult, respectively [163]. A value of $10^{-6}$ for ${ }^{129} \mathrm{I} /{ }^{127} \mathrm{I}$ ratio in thyroid means an amount of ${ }^{129} \mathrm{I}$ at about $10^{-9} \mathrm{~g}$ (or $6.55 \mathrm{mBq}$ ) and $10^{-8} \mathrm{~g}$ (or $65.5 \mathrm{mBq}$ ) on the assumption of 1 and $10 \mathrm{mg}$ stable iodine in thyroid for the one year old child and adult respectively. The corresponding equilibrium annual dose equivalent to the thyroid can be therefore calculated to be about $10^{-3} \mathrm{mSv} / \mathrm{y}$ for both one year child and adult. In an environment without direct contamination from nuclear facilities, ${ }^{129} \mathrm{I} /{ }^{127} \mathrm{I}$ ratio is much lower than $10^{-6}$, which implies an effective radiation dose to thyroid from the internal exposure of ${ }^{129} \mathrm{I}$ is less than $10^{-3} \mathrm{mSv} / \mathrm{y}$. This value is 40 times lower than the U.S. NRC regulation dose limit of $0.04 \mathrm{mSv} / \mathrm{y}$ for combined beta and photon emitting radionuclide to the whole body or any organ, and even 1000 time lower than the annual radiation dose of about $1 \mathrm{mSv}$ from natural background radiation [164]. The highest ${ }^{129} \mathrm{I} /{ }^{127} \mathrm{I}$ value reported is $10^{-4}$, in areas close to nuclear 
facility such as reprocessing plants [77, 98, 104-105, 108, 113], which corresponds to an annual radiation dose of $0.1 \mathrm{mSv} / \mathrm{y}$ to the thyroid. This value is only about 2.5 times higher than the regulation dose limit of $0.04 \mathrm{mSv} / \mathrm{y}$. All these calculations don't consider the uptake of stable iodine from the diet with low ${ }^{129} \mathrm{I}$ level. In order to prevent iodine deficiency disorder diseases, iodine was supplied as iodinated slat or in other form to humans (and animals). ${ }^{129} \mathrm{I} /{ }^{127} \mathrm{I}$ value in the iodinated food is much lower than the environmental level because stable iodine used for this purpose is normally produced from low ${ }^{129} \mathrm{I}$ source $\left({ }^{129} \mathrm{I} /{ }^{127} \mathrm{I}<10^{-9}\right)$. In this case the ${ }^{129} \mathrm{I} /{ }^{127} \mathrm{I}$ value in thyroid of humans or mammals will be significantly lower than the environmental level. This means a low radiation dose to the thyroid. Additionally, 10 times lower ${ }^{129} \mathrm{I} /{ }^{127} \mathrm{I}$ value has been reported in the human (and animal) thyroid compared to the surrounding environment [36]. This feature implies that even in regions with high ${ }^{129} \mathrm{I} /{ }^{127} \mathrm{I}$ value in the environment, the effective radiation dose of ${ }^{129} \mathrm{I}$ to human thyroid is still lower than the regulation dose limit at present level. It has been mentioned above that there is about $68000 \mathrm{~kg}$ of ${ }^{129} \mathrm{I}$ stored in unprocessed spend fuel until 2005 which is 10 times more than the ${ }^{129}$ I released to the environment $(<6000 \mathrm{~kg})$. With the increasing number of nuclear power reactors, more ${ }^{129} \mathrm{I}$ will be produced. If most of the spent fuel is going to be reprocessed, ${ }^{129} \mathrm{I}$ released to the environment may increase the ratio of ${ }^{129} \mathrm{I} /{ }^{127} \mathrm{I}$ to $10^{-3}$. In such a case, the annual dose to the thyroid may reach to $1 \mathrm{mSv} / \mathrm{y}$, which excess the regulation radiation dose limit of ${ }^{129} \mathrm{I}$ to thyroid $(0.04 \mathrm{mSv} / \mathrm{y})$ and comparable to the level of natural background radiation. Accordingly, from the view of radiation dose, ${ }^{129} \mathrm{I}$ is less toxic at the present level or even higher level in the future. Guent et al [165] estimated the radiation dose in a situation of high ${ }^{129} \mathrm{I}$ exposure through diet and drinking water and found that the estimated effective dose is only 30 and $60 \mathrm{mSv} / \mathrm{y}$ at an uptake of $153 \mu \mathrm{g}{ }^{129} \mathrm{I}$ per day for a one-year child and an adult, respectively.

\section{Summary and perspectives}

The human nuclear activities, especially the releases from the spent nuclear fuel reprocessing plants, are presently the main source of ${ }^{129} \mathrm{I}$ in the environment. The ${ }^{129} \mathrm{I}$ concentration in environmental samples has increased 3-8 orders of magnitude compared to pre-nuclear era level, and reached to $10^{-10}-10^{-4}$ for ${ }^{129} \mathrm{I} /{ }^{127} \mathrm{I}$ ratio. Despite the importance of ${ }^{129} \mathrm{I}$ speciation not only in radiation protection related to high mobility of iodine in nuclear waste depository and the environment and possible high bioavailability and concentration in human thyroid, but also in its application as an environmental tracer, the data are scarce. It is, therefore, the understanding of ${ }^{129} \mathrm{I}$ 
speciation in the environment represents a vital tool for tracing transport mechanisms, distribution pathways and bioavailability in the environment. To achieve that, specific chemical extraction methods and high sensitivity analytical techniques have been developed recently. The reported works on ${ }^{129}$ I speciation mainly focus on water and atmosphere, and fractionation of ${ }^{129} \mathrm{I}$ in soil and sediment. The methods used for speciation analysis of ${ }^{129} \mathrm{I}$ in water sample are based on anion exchange chromatography, and aimed for determination of iodide, iodate and organically associated iodine. ${ }^{129}$ I speciation in seawater has shown potential tracer capability of sources. The method used for speciation of ${ }^{129} \mathrm{I}$ in the atmosphere is based on trapping of different species by several filters, which separate ${ }^{129} \mathrm{I}$ in three fractions, particle associated, inorganic gaseous and organic gaseous iodine. A few data have shown that speciation of ${ }^{129} \mathrm{I}$ in atmosphere can supply useful information about the source and transfer pathway. The sequential extraction methods, normally used for various components of soil and sediment, have provided information about the water soluble, exchangeable, carbonate, oxides, organic and mineral associated ${ }^{129}$ I. Some of the results have indicated different fractionation pathways for of ${ }^{129} \mathrm{I}$ and ${ }^{127} \mathrm{I}$. Until now there are no published data about the speciation of ${ }^{129} \mathrm{I}$ in biological samples.

The bioavailability of ${ }^{129} \mathrm{I}$ is expected to be strongly dependent on its speciation, where iodide and iodate have a higher bioavailability (uptake by plants and animals) than the fraction associated with organic matters. The radiation toxicity of ${ }^{129} \mathrm{I}$ is relatively insignificant as the effective radiation dose to the thyroid is only about $1 \mu \mathrm{Sv} / \mathrm{y}$ at the present environmental level $\left({ }^{129} \mathrm{I} /{ }^{127} \mathrm{I}\right.$ of $10^{-}$ $\left.{ }^{6}\right)$. This is 1000 times lower than the radiation dose from the natural background radiation $(1 \mathrm{mSv} / \mathrm{y})$. Even in the heavily contaminated areas $\left({ }^{129} \mathrm{I} /{ }^{127} \mathrm{I}\right.$ of $\left.10^{-4}\right)$, the radiation dose $(0.1 \mathrm{mSv} / \mathrm{y})$ is still 10 times lower than the dose from the nature background, and 2 time lower than the dose from natural ${ }^{40} \mathrm{~K}$ in human body.

\section{Acknowledgements}

Authors (X.L. Hou \& V. Hansen) thank Villum Kann Rasmussen Foundation for financial support. The authors also wish to thank the NKS-B programme for support of the SPECIATION project, which provided possibilities for cooperation of the authors from Nordic countries on this article.

\section{List of abbreviation}

AMS: $\quad$ Accelerator mass spectrometry 
AmAD: $\quad$ activity median aerodynamic diameter

DIT: Diiodineothyrosine

DRC: $\quad$ Dynamic collision/reaction cell

EXAFS: $\quad$ extended X-ray absorption fine structure spectra

HpGe: High pure germanium

HPLC: $\quad$ High performance liquid chromatography

ICP-MS: $\quad$ Inductively coupled plasma mass spectrometry

LSC: liquid scintillation counter

MIT: $\quad$ Monoiodothyrosine

NAA: Neutron activation analysis

SIMS: $\quad$ Secondary ion mass spectrometry

T3: triiodothyronine

rT3: $\quad$ reverse triiodothyronine

T4: Thyroxine

TBAH: Tetrabutylammoniumhydroxide

TEDA: Triethylenediamine

TBP/OK: tri-n-butyl phosphate in odourless kerosene

XANES: $\quad$ X-ray absorption near-edge structure

\section{References}

[1] G.T.F. Wong, Review in Aquatic Science, 45 (1991) 45-73

[2] Y. Muramatsu \& K.H. Wedepohl, Chem. Geology, 147 (1998) 201-216

[3] B. Salbu, J. Environ. Radioact. 96 (2007) 47-53

[4] U. Fehn, G. Snyder, P.K. Egeberg, Science, 289 (2000) 2332-2335

[5] R.H. Nichols, G.M. Hohenberg, K. Kehm, Y. Kim, K. Marti, Cosmochim. Acta, 58 (1994) 2553-1561

[6] G.M. Raisbeck, F. Yiou, Z.Q. Zhou, L.R. Kilius, J. Mar. Syst. 6 (1995) 561-570

[7] G.M. Raisbeck, F. Yiou, Sci. Total Environ., 238 (1999) 31-41

[8] J.C. Gascard, G. Raisbeck, S. Sequeira, F. Yiou, K.A. Mork, Geophy. Res. Lett. 31 (2004) 101308

[9] J.N. Smith, E.P. Jones, S.B. Moran, W.M. Smethie, W.E. Kieser, J. geophys. Res. Oceans, 111 (2005) C05006.

[10] V. Alfimov, A. Aldahan, G. Possnert, Geophy. Res. Lett., 31 (2004) L19305

[11] V. Alfimov, A. Aldahan, G. Possnert, P. Winsor, Mar. Pollut. Bull. 49 (2004) 1097-1104

[12] N. Buraglio, A. Aldahan, G. Possnert, Geophy. Res. Lett. 26 (1999) 1011-1014

[13] X.L. Hou, H. Dahlgaard, S.P. Nielsen, Estuar. Coast. Shelf Sci., 51 (2000) 571-584 
[14] X.L. Hou, H. Dahlgaard, S.P. Nielsen, J. Kucera, J. Environ. Radiat. 61 (2002) 331-343

[15] X.L. Hou, A. Aldahan, S.P. Nielsen, G. Possnert, H. Nies, J. Hedfors, Environ. Sci. Technol. 41 (2007) 5993-5999.

[16] X.L. Hou, J. Radioanal. Nucl. Chem., 262 (2004) 67-75.

[17] K.A. Schwehr, P.H.Santschi, D. Elmore, Limnol. Oceanogr. Meth. 3 (2005) 326-337

[18] P.H. Santschi, K.A. Schwehr, Sci. Total Environ., 321 (2004) 257-271

[19] J. Fabrykamartin, H. Bentley, D. Elmore, P.L. Airey, Geochim. Cosmochim. Acta, 49 (1985) 337-346

[20] H. Wershofen, D.C. Aumann, J. Environ. Radioact. 10 (1989) 141-156

[21] K. Schmidtz, D.C.Aumann, J. Radioanal. Nucl. Chem., 198 (1995) 229-236

[22] X.L. Hou, C.L. Fogh, J. Kucera, K.G. Andersson, H. Dahlgaard, S.P. Nielsen, Sci. Total Environ. 308 (2003) 97-109

[23] X.L. Hou, H. Dahlgaard, S.P. Nielsen, Mar. Chem., 74 (2001) 145-155

[24] J.S. Edmonds, M. Morita, Pure Appl. Chem., 70 (1998) 1567-1584

[25] J.V. Christansen, The behaviour of iodine in the terrestrial environment. Risø-M-2851, Risø National Laboratory, Denmark, 1990.

[26] G.Snyder, U. Fehn, Nucl. Instr. Meth. B223-224 (2004) 579-586

[27] Z.F. Chai, Z.Y. Zhang, W.Y. Feng, C.Y. Chen, D.D. Xu, X.L. Hou, J. Anal. At. Spectrom., 19 (2004) 26-33

[28] R.G. Wuilloud, J.C. Altamirano, Current Anal. Chem., 2 (2006) 353-377

[29] R.G. Wuiloud, J.C. Altamirano, Speciation of halogencompounds, in E. Cornelis ed. Handbook of Elemental speciation II, John Wiley \& Sons Ltd, (2003) pp564-620

[30] X.L. Hou, Iodine speciation in foodstuff, tissues and environmental samples, in V. R Preedy ed. The comprehensive Handbook on Iodine, Elsevier, 2008, in press

[31] S. Yoshida, Y. Muramatsu, J. Radioanal. Nucl. Chem., 196 (1995) 295-302

[32] Y. Muramatsu, S. Yoshida, Geomicrobiol. J., 16 (1999) 85-93

[33] M. H. Gerzabek, Y. Muramatsu, F. Strebl, S. Yoshida, J. Plant Nutr. Soil Sci., 162 (1999) 415419

[34] X.L. Hou, X.J. Yan, Sci. Total Environ., 222 (1998) 141-156

[35] X.L.Hou, H. Dahlgaard, S.P. Nielsen, W.J.Ding, Sci. Total Environ., 246 (2000) 285-291.

[36] X.L. Hou, H. Dahlgaard, S.P. Nielsen, A.F. Malencheko, J. Kucera, Sci. Total Environ. 302 (2003) 61-71

[37] X.L. Hou, C.F. Chai, Q.F. Qian, C.S. Li, Q. Chen, Biol. Trace Elem. Res., 56 (1997) 225-230

[38] Y.Liu, H.R. Gunten, Migration chemistry and behaviour of iodine relevent to geological disposal of radioactive wastes. A literature review with a compilation of sorption data, PSI-16, 1988, Paul Scherrer Inst., Switzerland.

[39] R. Michel, K. Klipsch, Th.Ernst, M. Gorny, D.Jakob, J. Vahlbruch, H -A. Synal, C. Schnabel, Ableitung von radioökologischen Parametern aus dem langfristigen Eintrag von Iod-129 (in German) Abschlussbericht zum Forschungsvorhaben StSch 4285, August 2004, in: Schriftenreihe Reaktorsicherheit und Strahlenschutz, BMU - 2004 - 650, ISSN 1612-6386, http://www.bmu.de/strahlenschutz/doc/6872.php und www.zsr.uni-hannover.de

[40] C. Schall, K.G. Heumann, G.O. Kirst, Fresenius J. Anal. Chem. 359 (1997) 298-305

[41] R.M. Moore, W. Graszko, W. J. Geophys. Res. 104 (1999) 11163-11171

[42] X.L. Hou, C.F. Chai, Q.F. Qian, X.J. Yan, X. Fan, Sci. Total Environ. 204 (1997) 215-221

[43] X.L. Hou, X.J. Yan, C.F. Chai, J. Radioanal. Nucl. Chem. 245 (2000) 461-167 
[44] G.W. Luther, T. Ferdelman, C.H. Culberson, J. Kostka, J.F.Wu, J.F. Estuar. Coast. Shelf Sci. 32 (1991) 267-279

[45] N. W. Truesdale, G. Nausch, A. Baker, Mar. Chem. 74 (2001) 87-98

[46] G.T.F.Wong, Deep-Sea Res. Part I, 42 (1995) 2005-2023

[47] S.D. Jones, V.W. Truesdale, Limnol. Oceanogr. 29 (1984) 1016-1028

[48] K. A. Schwehr, P. H. Santschi, Anal. Chim. Acta 482 (2003) 59-71

[49] M.L.A.M. Campos, P.D. Nightingale, T.D. Jickells, Tellus 48B (1996) 106-114

[50] S. Solomon, S.R. Garcia, A.R. Ravishankara, J. Geophy. Res. 99 (1994) 20491-20499

[51] J.P. Greeberg, A.B. Guenther, A. Turnipseed, Environ. Chem., 2 (2005) 291-294

[52] V.W. Truesdale, S.D. Jones, J. Hydrology 179 (1996) 67-86

[53] P. Vaattovaara, P.E. Huttunen, Y.J. Yoon, J. Joutsensaari, K.E.J. Lehtinen, C.D. O’Dowd, A. Laaksonen, Atmos.Che. Phys., 6 (2006) 4601-4616

[54] B.S. Gilfedder, M. Petri, H. Biester, J. Geophys. Res. Atmosph. 112 (2007) D07301.

[55] M.A.R. Abdel-Moati, Marine Chemistry, 65 (1999) 211-225

[56] C. Reifenhäuser, K. Heumann, Fresenius J. Anal. Chem., 336 (1990) 559-563

[57] X.L. Hou, C.Y. Chen, W.J. Ding, C.F. Chai, Biol. Trace Elem., 68 (1999) 69-76

[58] R. Simon, J.E.Tietge, B. Michalke, S. Degitz, K.W. Schramm, Anal. Bioanal. Chem. 372 (2000) 481-485

[59] P. Brätter, I.N. Blasco, V.E. Negretti de Brätter, A. Raab, Analyst 123 (1998) 821-826

[60] B. Michalke, Pure Appl. Chem. 78 (2006) 79-90

[61] M. Leiterer, D. Truckenbrodt, K. Franke, European Food Res. Technol. 213 (2001)150-153

[62] M. Shah, R.G. Wuilloud, S.S. Kannamkumaratha, J.A. Caruso, J. Anal. At. Spectrom. 20 (2005) 176-182

[63] F.C. Küpper, L.J.Carpenter, G.B.McFiggans, C.J. Palmer, T.J.Waite, E.M. Boneberg, S.Woitsch, M. Weiller, R.Abela, D.Grolimund, P.Potin, A. Butler, G.W.LutherIII, P.M.H.Kroneck, W.Meyer-Klaucker, M.C. Feiters, PNAS 105(2008) 6954-6958.

[64]. C.J. Palmer, T.L. Anders, L.J Carpenter, F.C. Kupper, G.B Mcfiggans, Environ. Chem., 2 (2005) 282-290.

[65] R. von Glasow, Environ. Chem., 2 (2005) 243-244.

[66] C.D. O’Dowd, J.L. Jimenez, R. Bahreini, R.C. Flagan, J.H. Seinfeld, K. Hameri, L. Pirjola, M. Kulmala,, S.G. Jennings, T. Hoffmann, Nature, 417 (2002) 632-636.

[67] K. Sellegri, Y.J. Y.J. Loon, S.G. Jennings, C.D. O’Dowd, L. Pirjola, S. Cautenet, H.W. Chen, T. Hoffmann, Environ. Chem., 2 (2005) 260-270.

[68] M.V. Frontasyeva, E. Steinnes, J. Radioanal. Nuc. Chem., 261 (2004) 101-106

[69] H.E. Gabler, K.G. Heumann, Intern. J. Environ. Anal. Chem., 50 (1993) 129-146.

[70] H. Noguchi, M. Murata, J. Environ. Radiat. 7 (1988) 65-74

[71] H.E. Gabler, K.G. Heumann, Fresenius J. Anal. Chem. 345 (1993) 53-59

[72] K.A. Rahn, R.D. Borys, R.A. Duce, Science 192 (1976) 549-550

[73] A.R. Baker, Geophy. Res. Lett. 31 (2004), L23S02.

[74] A.R. Baker, C. Tunnicliffe, T.D. Jickells, J. Geophys. Res. Atmos., 106 (2001) 28743-28749.

[75] A.R. Baker, Env. Chem., 2 (2005) 295-298

[76] J. Stutz, K. Hebestreit, B. Alicke, U. Platt, J. Atmos, Chem. 34 (1999) 65-85

[77] B.T. Wilkins, Investigations of ${ }^{129} \mathrm{I}$ in the natural environment. results and implications, NRPB-R225, National Radiaological protection Board, UK, 1989 
[78] K. Yuita, Soil Sci. Plant Nutr. 38 (1992) 281-287

[79] R.R. Edwards, Science, 137 (1962) 851

[80] NCRP, Iodine-129: Evaluation of releases from nuclear power generation. NCRP Report No.75 (National Council on Radiation Protection and Measurements, Bethesda MD), 1983

[81] U. Fehn, G.R. Holdren, D. Elmore, T. Brunelle, R. Teng, P.W, Kubik, Geophys. Res. Lett. 13 (1986) 137-139

[82] J.E. Moran, U. Fehn, R.T.D. Teng, Chem. Geol. 152 (1998) 193-203

[83] L.R. Kilius, A.E. Litherland, J.C.Rucklidge, N.Baba, Appl. Radiat. Isot. 43 (1992) 279

[84] J.E. Moran, A. Oktay, P.H. Santschi, D.R. Schink, Environ. Sci. Technol. 33 (1999) 25362542

[85] J. Handl, E.Oliver, D. Jakob, K.J. Johanson, P. Schuller, Health Phys. 65 (1993) 265

[86] R. Seki, E. Kimura, T. Takahashi, N. Ikeda, J. Radioanal. Nucl. Chem. 138 (1990) 17-31

[87] L.W. Cooper, T.M.Beasley, X.L.Zhao, C. Soto, K.L. Vinogradova, K.H. Dunton, Mar. Biol. 131(1998) 391

[88] U. Rao, U. Fehn, Cosmochim. Acta, 163(1999)1927-1939

[89] H. Reithmeier, V. Lazarev, W. Rühm, M. Schwikowski, H. Gäggeler, E. Nolte, Environ. Sci. Technol. 40 (2006) 5891-5896

[90] D.R. Schink, P-H. Santschi, O. Corapcioglu, P. Sharma, U. Fehn, Earth and Planet. Sci. Lett. 135 (1995) 131-138

[91] T. Suzuki, S. Kabuto, H. Amano, O. Togawa, Quaternary Geochronology, 3 (2007) 268-275

[92] D. Gallagher, E.J. Mcgee, P.I. Mitchell, V. Alfimov, A. Aldahan, G. Possnert, Environ. Sci. Technol., 39 (2005) 2927-2935

[93] M. Paul, D. Fink D. G. Hollos, A. Kaufman, W. Kutschera, M. Magaritz, Nucl. Instr. Meth. B29 (1987) 341-345

[94] T. Straume, L.R. Anspaugh, A.A. Marchetti, G. Voigt, V. Minenko, F. Gu, P. Men, S. Trofimik, S. Tretyakevich,V.Drozdovitch, E. Shagalova, O. Zhukova M. Germenchuk, S. Berlovich, Health Phys. 91 (2006) 7-19

[95] V. Mironov, V. Kudrjashov, F.Yiou, G.M. Raisbeck, J. Environ. radioact. 59 (2002) 293-307

[96] A. Aldahan, V. Alfimov, G. Possnert, Applied Geochem., 228 (2007) 606-618

[97] IAEA, Energy, Electricity and nuclear power: Developments and Projections, International Atomic Energy Agency, STI/PUB/1304, 2007, http://wwwpub.iaea.org/MTCD/publications/PDF/Pub1304_web.pdf

[98] B.G. Fritz, G. W. Patton, J. Environ. Radioact. 86 (2006) 64-77

[99] A.W. Castleman, I. N. Tang, H. R. Munkelwitz, J. Inorg. Nucl. Chem., 30 (1968) 5-13

[100] W.A. Reed, I. May, F.R. Livens, J.M. Charnock, A.P. Jeapes,M. Gresley, R.M.Mitchell, P.Knight, J. Anal. At. Spectrom., 17 (2002) 541-543.

[101] J. Gray, S.R. Jones, A.D. Smith, J. Radiol. Prot., 15 (1995), 99-131.

[102] IRRIN, Inventaire des rejets radioactifs des installation nuceairs, Groupe Radioecologie Bord Contentin, Vol.1. 1999.

[103] F. Yiou, G.M. Raisback, G.C. Christensen, E. Holm, J. Environ. Radiat., 60 (2002) 61-71

[104] C. Frechou, D. Calmet, Czechslovak J. Phys. 53 (2003) A83-A89

[105] C. Frechou, D. Calmet, J. Environ. Radiat. 70 (2003) 43-59

[106] D. Maro, D.Hebert, R. Gandon, L. Solier, Radioprotection, 34 (1999) 13-24.

[107] C. Schnabel, V. Olive, M. Atarashi-Andoh, A. Dougans, R.M. Ellam, S. Freeman, C. Maden, M. Stocker, H. A. Synal, L. Wacker, S. Xu, S. Appl. Geochem. 22(2007), 619-627. 
[108] S. M. Keogh, A. Aldahan, G. Possnert, P. Finegan, L. Leon Vintro, P.I. Mitchell, J. Environ. Radioact. 95 (2007) 23-38

[109] C. Duffa, C. Frechou, Appl. Geochem., 18 (2003) 1867-1873

[110] HHIN, The Release of Radioactive Materials from Hanford: 1944-1972, The Hanford Health Information Network (HHIN), http://www.doh.wa.gov/hanford/publications/history/release.html

[111] K. Shinohara, J. Radioanal. Nucl. Chem. 260 (2004) 265-271

[112] JAEA, Annual report on the effluent control of low level liquid wate in nuclear fuel cycle eneineering laboratories FY 2005, http://jolissrch-inter.tokai-sc.jaea.go.jp/pdfdata/JAEAReview-2006-024.pdf

[113] E. Robens, D.C. Aumann, J. Environ. Radioact. 7 (1988) 159-175

[114] Y. Muramatsu, Y. Ohmom, M. Sumiya, J. Radioanal. Nucl. Chem. Art., 123 (1988) 181-189

[115] R.E. Jaquish and K.R. Price, Iodine-129: environmental monitoring and population dose in the Hanford environs PNL-SA-16066, Pacific Northwest Laboratory, Richland, Washington, 1988.

[116] G.R. Doshi, S.N. Joshi, K.C. Pillai, J. Radioanal. Nucl. Chem. Lett., 155 (1991) 115-127

[117] J.A. Suarez, A.G. Espartero, M. Rodriguez, Nucl. Instr. Meth. A369 (1996) 407-410.

[118] P.Bouisset, O. Lefevre, X. Cagnat, G. Kerlau, A. Ugron, D.Calmet, Nucl. Instr. Meth. A437(1999) 114-127

[119] M.H. Studier, C. Postmus, J. Mech, R.R. Walters, E.N. Sloth, J. Inorg. Nucl. Chem., 24 (1962) 755-761

[120] X.L. Hou, H. Dalhgaard, B. Rietz, U. Jacobsen, S.P.Nielsen, A. Aarkrog, A. Analyst, 124 (1999) 1109-1114.

[121] D.C. Auman, Radiochimica Acta 29 (1981) 209-215

[122] Y. Muramatsu, Y.Ohmomo, D.J. Christoffers, Radioanal. Nuclear Chem. Art., 83 (1984) 353-361

[123] S.J. Parry, B.A. Bennett, R. Benzing, A.E. Lally, C.P. Birch, M.J. Fulker, Sci. Total Environ., 173/174 (1995) 351-360

[124] N. Buraglio, A. Aldahan, G. Possnert, Nucl. Instr. Meth., B161 (2000) 240-244.

[125] A. Aldahan, A. Kekli, G.Possnert, J. Environ. Radioact., 88 (2006) 49-73

[126] N. Buraglio, A. Aldahan, G. Possnert, I.Vintersved, Environ. Sci. Technol., 35 (2001) 15791586

[127] R. Michel, J. Handl, T. Ernst, W. Botsch, S. Szidt, A. Schmidt, D. Jakob, D. Beltz, L.D.Romantschuk, H.A.Synal, C. Schnabel, J.M. Lopez-Gutierrez, Sci. Total Environ., 340 (2005) 35-55

[128] C. Schnabel C, J.M. Lopez-Gutierrez, S. Szidat, M. Sprenger, H. Wernli, J. Beer, H.A.Synal, Radiochim. Acta, 89 (2001) 815-822

[129] Z. Lu, U. Fehn, H. Tomaru, D. Elmore, X. Ma, Nucl. Instr. Meth. B 259 (2007) 359-364

[130] F. Yiou, G. Raisbeck, H. Imbaud, Nucl. Instr. Meth., B223 (2004) 412-415

[131] R.J. Cox, C.J. Picford, M.Thompson, J. Anal. Atom. Spectrom., 7 (1992) 635-640

[132] O.T. Farmer, C.J. Barinaga, D.W. Koppenaal, J. Radioanal. Nucl. Chem., 234 (1998) 153157

[133] P. Bienvenu, E. Brochard, E. Excoffier, M. Piccione, Can. J. Anal. Sci. Spectros. 49 (2004) 423-429

[134] A.V. Izmer, S.F. Boulyga, J.S. Becker, J. Anal. At. Spectrom. 18 (2003) 1339-1345.

[135] A.V. Izmer, S.F. Boulyga, M.V. Zoriy , J.S. Becker, J. Anal. At. Spectrom. 19 (2004) 1278- 
1280.

[136] C.F. Brown, K.N. Geiszler, M.J. Lindberg, Appl. Geochem., 22 (2007) 648-655.

[137] X.L. Hou, V. Hansen, A. Aldahan, G. Possnert, A simple Method for the Speciation Analysis of ${ }^{129}$ I in Seawater, Proceedings of $11^{\text {th }}$ International conference in accelerator mass spectrometry, Rome, Sept. 2008

[138] T. Nedveckaite, W. Filistowicz, J. Radioanal. Nucl. Chem, Art., 174 (1993) 43-47

[139] H. Tsukada, J.Ishida, O. Narita, Atmos. Environ., 25A (1991) 905-908

[140] R. Fuge, C. C. Johnson, Geochem. Health, 8 (1986) 31-54

[141] G. Krupp, D.C. Aumann, Chem. Erde 59 (1999) 57-67

[142] B. C. Sive, R.K. Varner, H. Mao, D. R. Blake, O. W. Wingenter, Geophy. Res. Lett. 34 (2007)L17808

[143] H. Tsukada, J. Ishida, O. Narita, Atmos. Environ., 25A (1991) 905-908

[144] E.A. Bondietti, J. N. Brantley, Nature, 322 (1986) 313-314

[145] R.H. Knuth, C.G. Sanderson, Particle size distribution of Chernobyl related aerosols in New York City, USDOE rep. EML-460, 291-300, 1986

[146] A. Tessier, P.G.C. Campbell, M. Bisson, Anal. Chem., 51 (1971) 844-851

[147] R. Petersen, X.L. Hou, E.H. Hansen, J. Environ. Radioact., 99 (2008) 1165-1174

[148] E. Englund, X.L. Hou, A. Aldahan, G. Possnert, Sequential leaching of Iodine isotopes (127 and 129) in sediment, Proceedings of $11^{\text {th }}$ International conference in accelerator mass spectrometry, Rome, Sept. 2008

[149] D.G. Schulze, P.M. Bertsch, Synchrotron X-ray techniques in soil, plant, and environmental research. In: Advances in Agronomy, 55 Elsevier, (1995) pp. 1-66.

[150] M.C. Feiters, F.C.Kupper, W. Meyer-Klaucke, J. Synchrotron Radiat. 12 (2005) 85-93

[151] R.J. Silva, H. Nitsche, Environmental actinide science. Mrs Bulletin 26 (2001) 707-713.

[152] S.D. Conradson, XAFS - A Technique to Probe Local Structure. Los Alamos Science 26 (2000) 422-435.

[153] Y.S. Shimamoto, Y. Takahashi, Anal. Sci., 24 (2008) 405-409.

[154] Schlegel, M.L., Reiller, P., Mercier-Bion, F., Barre,V. Moulin, Geochim. Cosmochim. Acta 70 (2006) 5536-5551.

[155] T. Bacquart, G. Deves, A. Carmona, R. Tucoulou, S. Bohic, R. Ortega, Anal. Chem., 79 (2007) 7353-7359.

[156] B. Michalke, P. Schramel, Eletrophoresis, 20 (1999) 2547-2553

[157] B. Michalke, P. Schramel, H. Witte, Biol. Trace Elem. Res., 78 (2000) 67-79

[158] L.F. Sanchez, J. Szpunar, J. Anal. Atomic Spectrom., 14 (1999) 1697-1702

[159] E. Robens, J. Hauschild, D.C. Aumann, J. Environ. Radioact., 8 (1988) 37-52

[160] R. Aquaron, F. Delange, P. Marchal, V. Lognone, L. Ninane, Cellular and Molecular Biology 48 (2002) 563-569.

[161] G. Jahreis, W. Hausmann, G. Kiessling, K. Franke, M. Leitere, Experimental and Clinic Endocrinology and Diabetes 109 (2001) 163-167

[162] R. Wahl, K.W. PilzMittenburg, W. Heer, E. Kallee, Zeitschrift Fur Ernahrungswissenschaft 34 (1995) 269-276

[163] J.K. Soldat, Radiation doses from ${ }^{129}$ I in the environment, Health Phys., 30 (1976) 61-70.

[164] D.W. Moeller, M. T. Ryan, Health Phys., 86 (2004) 586-589

[165] B. Le Guent, J.L. Malarbet, M. Roy, A. Aurengo, C. Devillers, H. Metivier, Radiat. Protect. Dosim., 79 (1998) 211-214 
Table 1 Nuclear properties and production model of iodine isotopes with half-life more than 10 min.

\begin{tabular}{|c|c|c|c|c|}
\hline Isotope & Half-life & $\begin{array}{l}\text { Decay } \\
\text { mode }\end{array}$ & $\mathrm{E}_{\max }, \mathrm{keV}$ & $\begin{array}{l}\text { Main } \gamma \text {-X-ray energy, keV } \\
\text { (abundance) }\end{array}$ \\
\hline${ }^{123} \mathrm{I}$ & $13.27 \mathrm{~h}$ & $\mathrm{EC}+\beta^{+}$ & $1074.9(97 \%, \mathrm{EC})$ & $159(83 \%)$ \\
\hline${ }^{124} \mathrm{I}$ & $4.18 \mathrm{~d}$ & $\mathrm{EC}+\beta^{+}$ & $\begin{array}{l}2557(25 \%, \mathrm{EC}), 3160 \\
(24 \%, \mathrm{EC}), 1535\left(12 \%, \beta^{+}\right), \\
2138\left(11 \%, \beta^{+}\right)\end{array}$ & $\begin{array}{l}602.7(63 \%), 723(10 \%) \\
1691(11 \%)\end{array}$ \\
\hline${ }^{125} \mathrm{I}$ & $59.41 \mathrm{~d}$ & $\mathrm{EC}$ & $150.6(100 \%)$ & $\begin{array}{l}35.5(6.68 \%), 27.2(40 \%) \\
27.5(76 \%)\end{array}$ \\
\hline${ }^{126} \mathrm{I}$ & $13.11 \mathrm{~d}$ & $\begin{array}{l}\mathrm{EC}+\beta^{+}, \\
\beta^{-}\end{array}$ & $\begin{array}{l}869.4\left(32 \%, \beta^{-}\right), 1489 \\
(29 \%, \mathrm{Ec}), 2155(23 \%, \mathrm{EC})\end{array}$ & $338.6(34 \%), 666.3(33 \%)$ \\
\hline${ }^{127} \mathrm{I}$ & Stable & & & \\
\hline${ }^{128} \mathrm{I}$ & $24.99 \mathrm{~m}$ & $\begin{array}{l}\beta^{-} \\
\mathrm{EC}+\beta^{+}\end{array}$ & $2119\left(80 \%, \beta^{-}\right)$ & $442.9(17 \%)$ \\
\hline${ }^{129} \mathrm{I}$ & $1.57 \times 10^{7} \mathrm{y}$ & $\beta^{-}$ & $154.4(100 \%)$ & $\begin{array}{l}39.6(7.5 \%), 29.5(20 \%) \\
29.8(38 \%)\end{array}$ \\
\hline${ }^{130} \mathrm{I}$ & $12.36 \mathrm{~h}$ & $\beta^{-}$ & $587(47 \%), 1005(48 \%)$ & $\begin{array}{l}536(99 \%), 668.5(96 \%), \\
739.5(82 \%)\end{array}$ \\
\hline${ }^{131} \mathrm{I}$ & $8.02 \mathrm{~d}$ & $\beta^{-}$ & $606(90 \%)$ & $364.5(82 \%)$ \\
\hline${ }^{132} \mathrm{I}$ & $2.30 \mathrm{~h}$ & $\beta^{-}$ & $\begin{array}{l}738(13 \%), 1182(19 \%), \\
2136(19 \%)\end{array}$ & $667.7(99 \%), 772.6(76 \%)$ \\
\hline${ }^{132 \mathrm{~m}} \mathrm{I}$ & $1.39 \mathrm{~h}$ & $\mathrm{IT}, \beta^{-}$ & $1483\left(8.6 \%, \beta^{-}\right)$ & $600(14 \%), 173.7(8.8 \%)$ \\
\hline${ }^{133} \mathrm{I}$ & $20.8 \mathrm{~h}$ & $\beta^{-}$ & $1240(83 \%)$ & $529.9(87 \%)$ \\
\hline${ }^{134} \mathrm{I}$ & $52.5 \mathrm{~m}$ & $\beta^{-}$ & $1307(30 \%)$ & $847(95 \%), 884(65 \%)$ \\
\hline${ }^{135} \mathrm{I}$ & $6.57 \mathrm{~h}$ & $\beta^{-}$ & $970(22 \%), 1388(24 \%)$ & $1260(29 \%)$ \\
\hline
\end{tabular}

Half lives of the isotopes are given as m: minutes; h: hours; d. days; and y: years. The decay model: EC for electron capture; $\beta^{+}$for positron emission; $\beta^{-}$for beta emission; IT for internal transfer. An isotope may decay by more than one model. 
Table 2 Sources, inventory/releases and environmental level of ${ }^{129} \mathrm{I}$

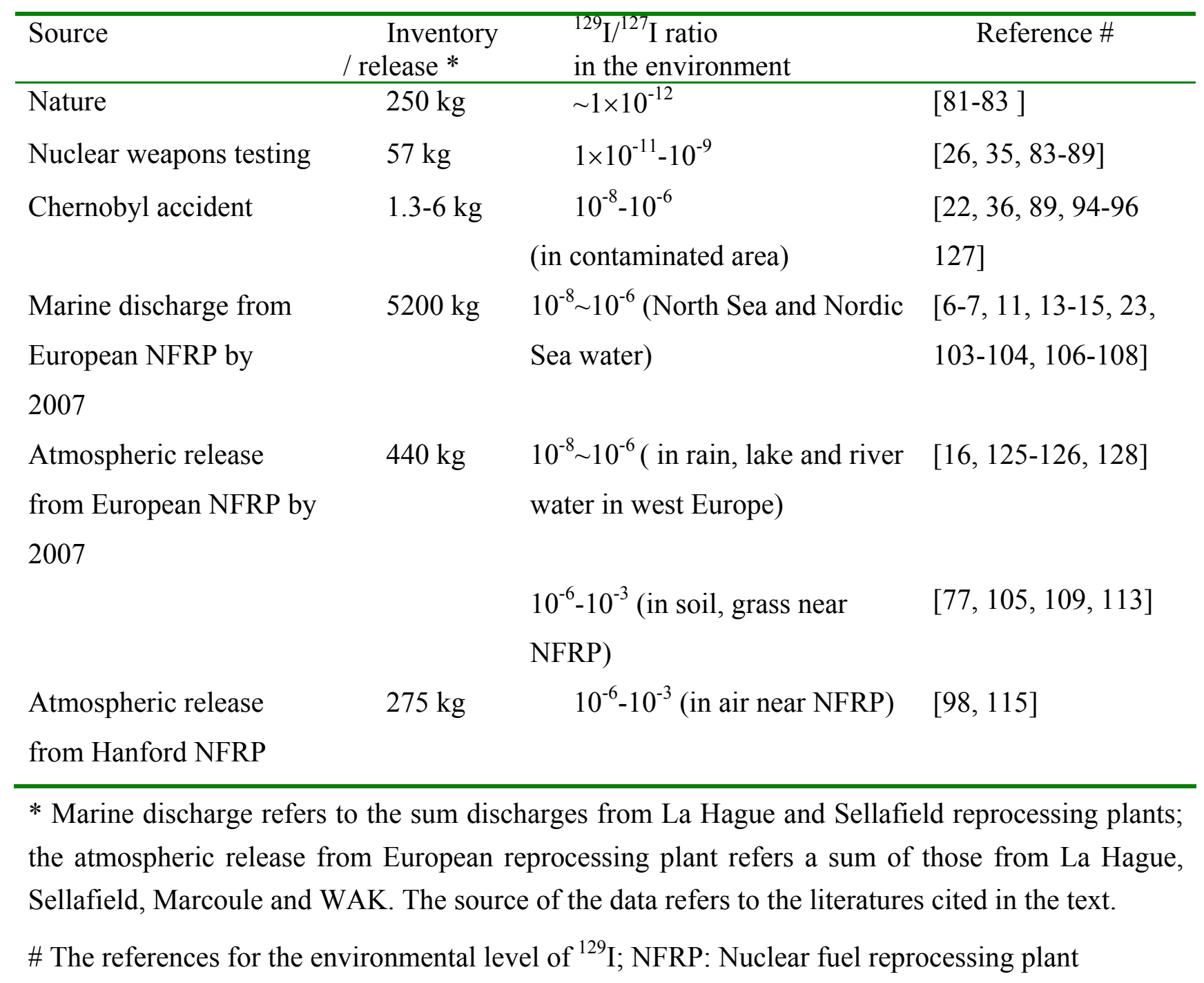


Table 3 Comparison of measurement methods for the determination of ${ }^{129} \mathrm{I}$

\begin{tabular}{ccccc}
\hline Detection method & Target preparation & \multicolumn{2}{c}{ Detection limit } & $\begin{array}{c}\text { Reference } \\
\text { number }\end{array}$ \\
\cline { 3 - 4 } X- $\gamma$ spectrometry & Direct measurement & $100-200 \mathrm{mBq}$ & $10^{-4}-10^{-5}$ & {$[106]$} \\
X- $\gamma$ spectrometry & Separated iodine $(\mathrm{AgI})$ & $20 \mathrm{mBq}$ & $10^{-5}-10^{-6}$ & {$[117]$} \\
LSC & Separated iodine & $10 \mathrm{mBq}$ & $10^{-5}-10^{-6}$ & {$[117]$} \\
RNAA & Separated MgI $/ \mathrm{I} 2$ & $1 \mu \mathrm{Bq}$ & $10^{-10}$ & {$[120]$} \\
& absorbed on charcoal & & & \\
AMS & AgI & $10^{-9} \mathrm{~Bq}$ & $10^{-13}$ & {$[124]$} \\
ICP-MS & Direct water & $40-100 \mu \mathrm{Bq} / \mathrm{ml}$ & $10^{-5}-10^{-6}$ & {$[136]$} \\
ICP-MS & measurement & & \\
\hline
\end{tabular}




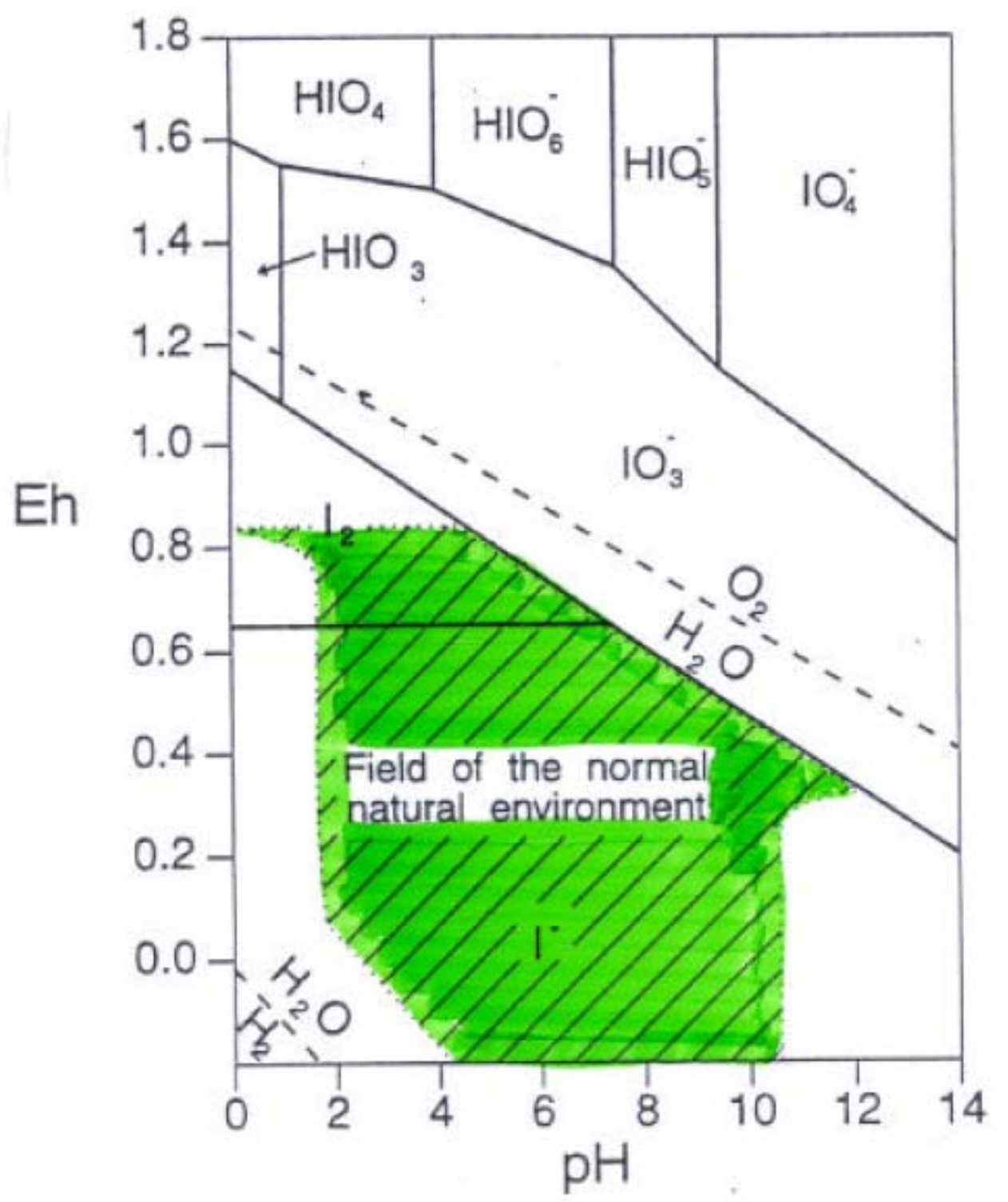

Fig. 1 Eh-pH diagram for iodine in water at $25^{\circ} \mathrm{C}$ [38-39] 


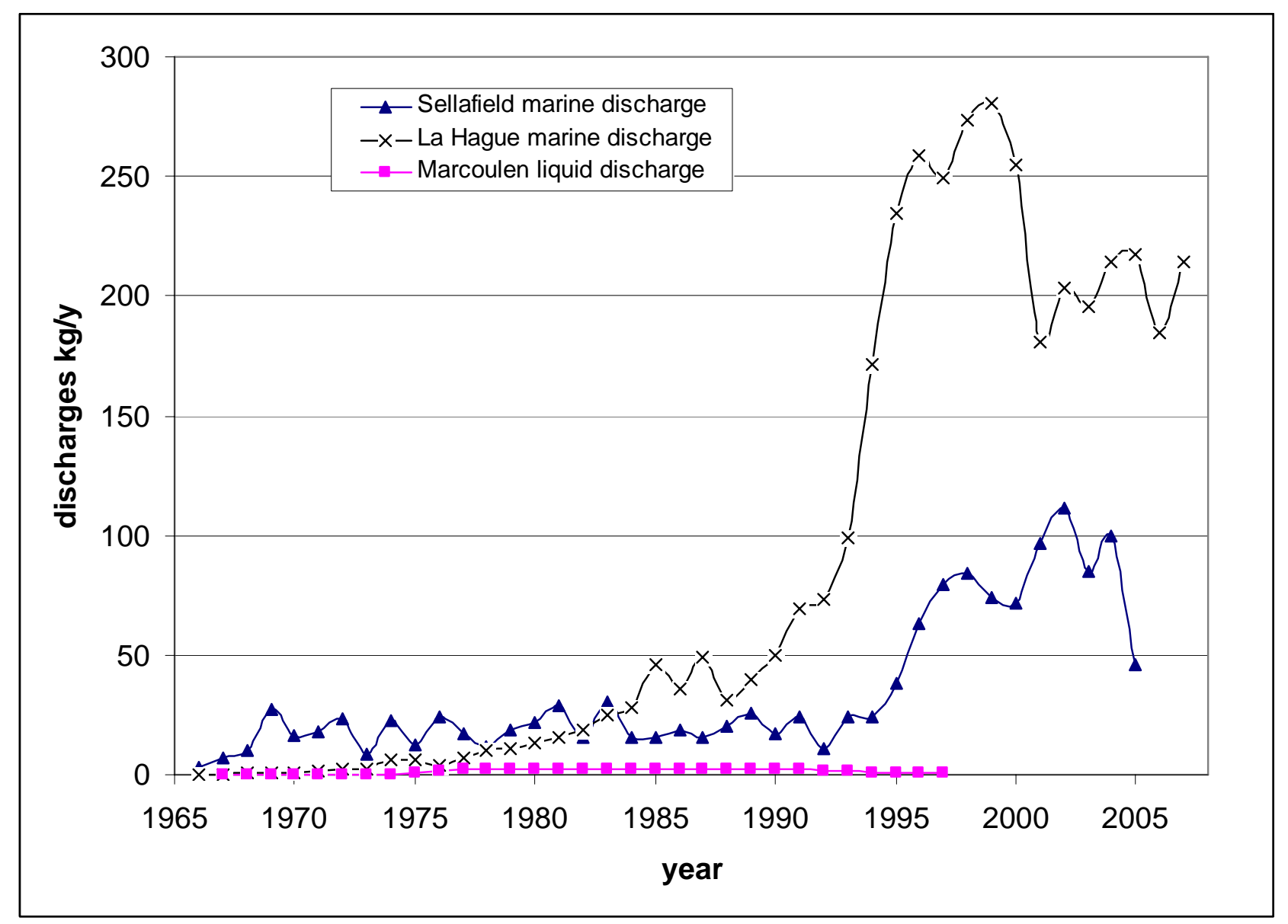

Fig. 2 Liquid Discharges of ${ }^{129}$ I from spent nuclear fuel reprocessing plants at La Hague (France), Marcoule (France) and Sellafield (UK) (literature refers to the text) 


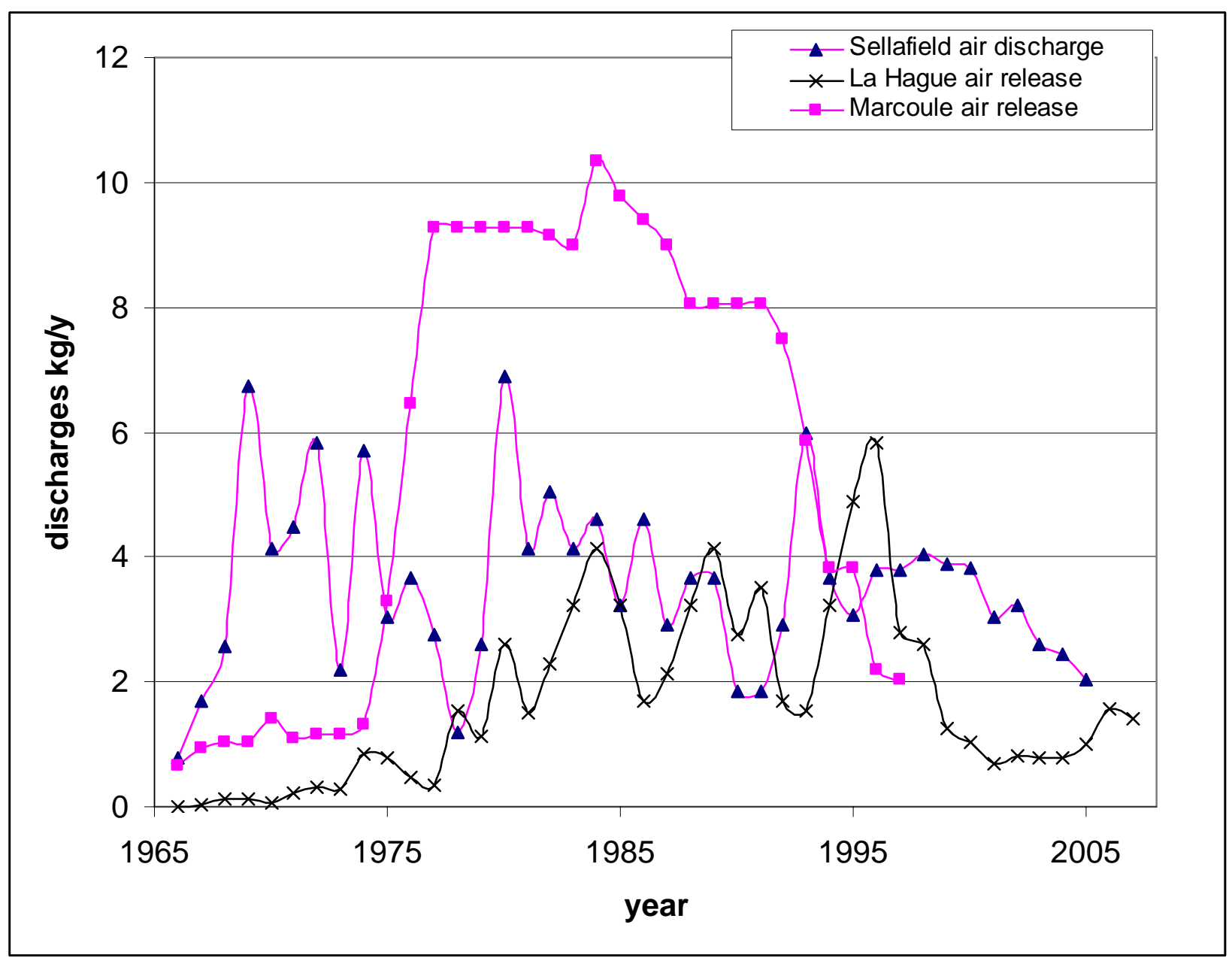

Fig. 3 Atmospheric releases of ${ }^{129}$ I from spent nuclear fuel reprocessing plants at La Hague (France), Marcoule (France) and Sellafield (UK) 


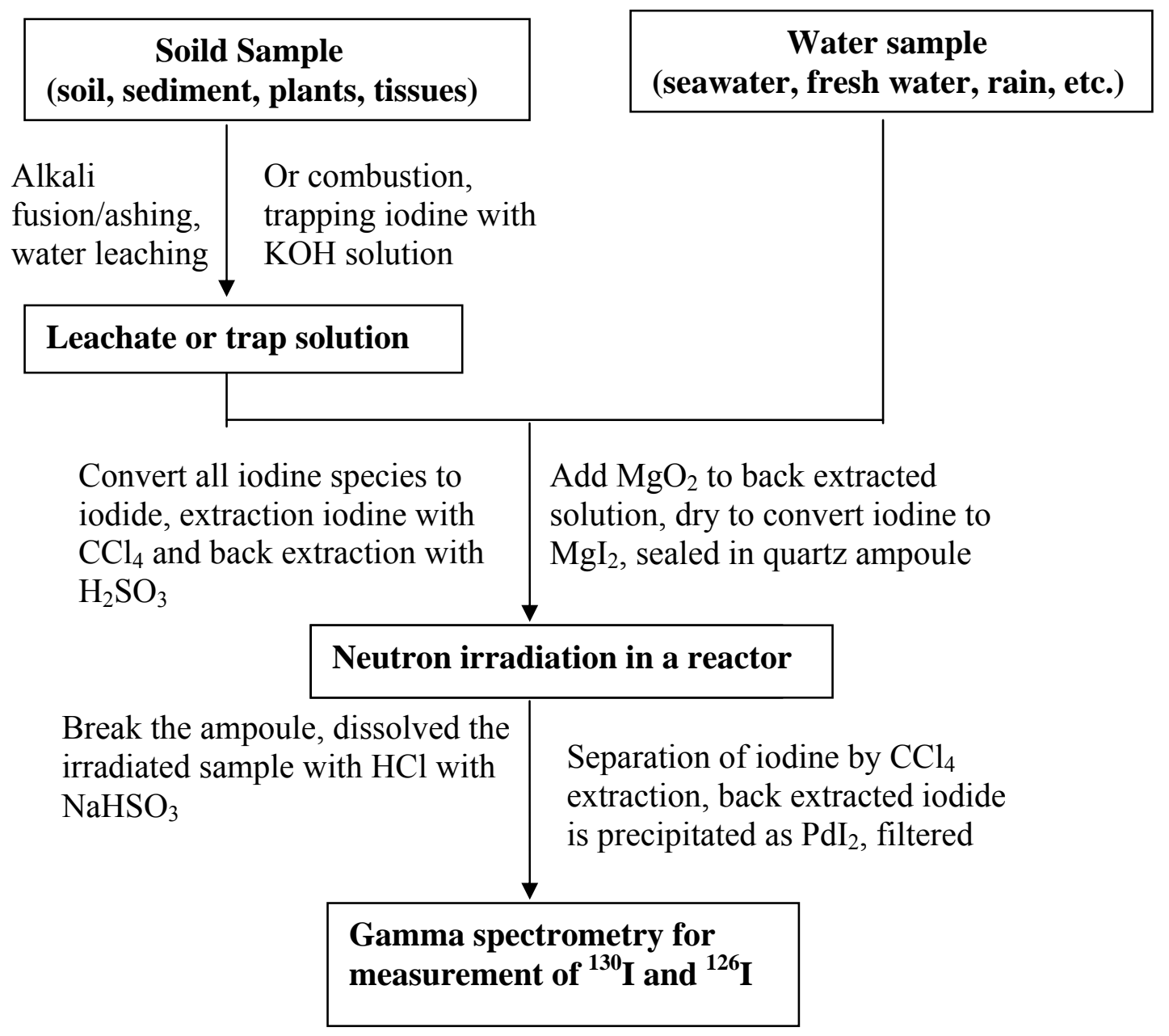

Fig. 4 Diagram of analytical procedure for determination of ${ }^{129}$ I by radiochemical NAA 

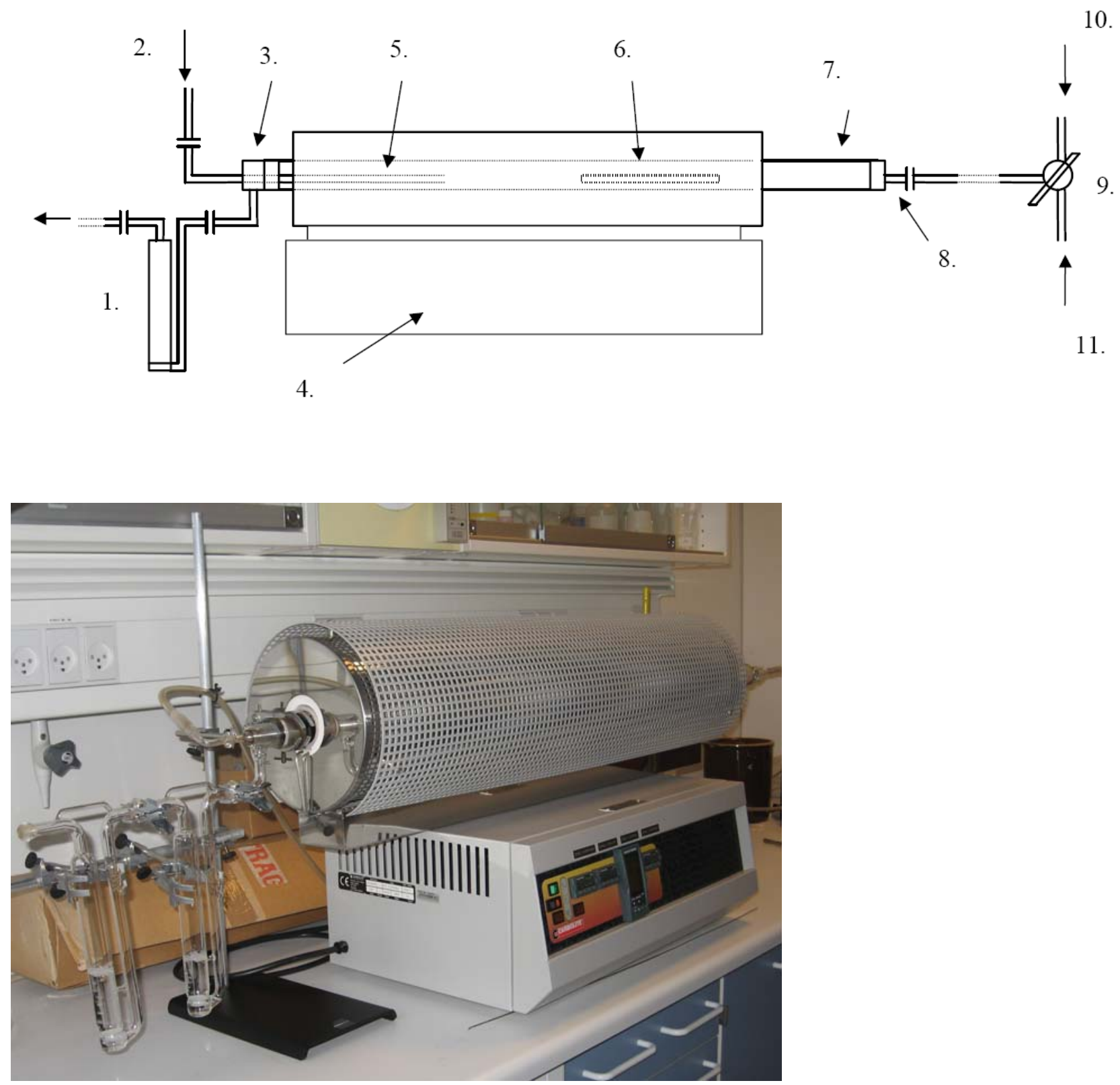

Figure 5 Schematic diagram and picture of combustion facility (Carbolite, UK) for the separation of iodine from solid sample. 1) Gas bubbler (filling with $\mathrm{NaOH}$ solution for trapping iodine); 2) Oxygen supply; 3) Exhaust gas manifold; 4) Temperature controller of combustion furnace; 5) Second furnace (for complete combustion of residue from first furnace); 6) sample boat in the first furnace; 7) Quartz working tube; 8) gas inlet adaptor; 9) Three ways valve; 10) main oxygen supply; 11) Compressed air supply (In the beginning of combustion, air is supplied to avoid a violet combustion under pure oxygen condition) 


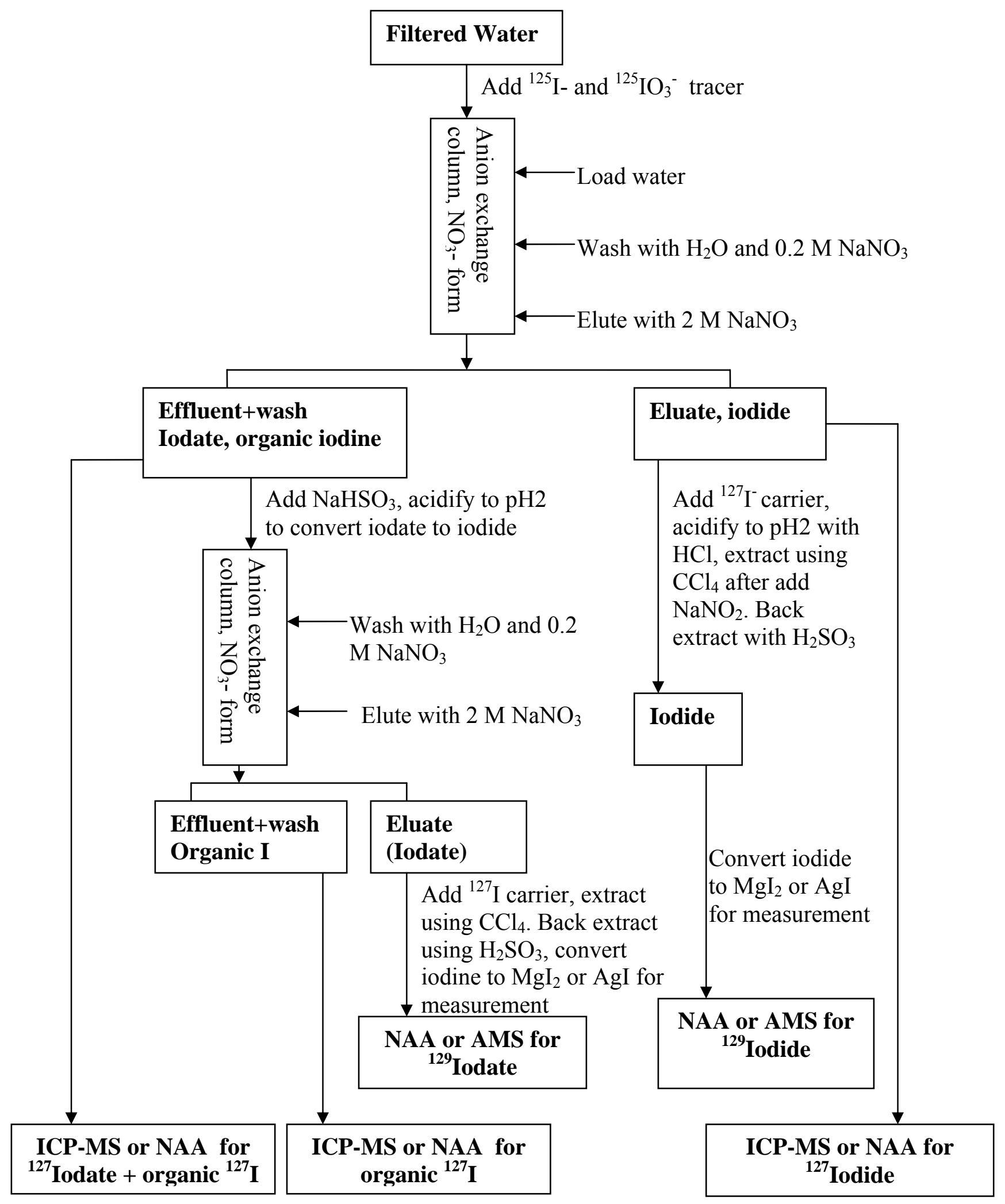

Fig. 6 Chemical procedure for speciation analysis of iodine in water sample 


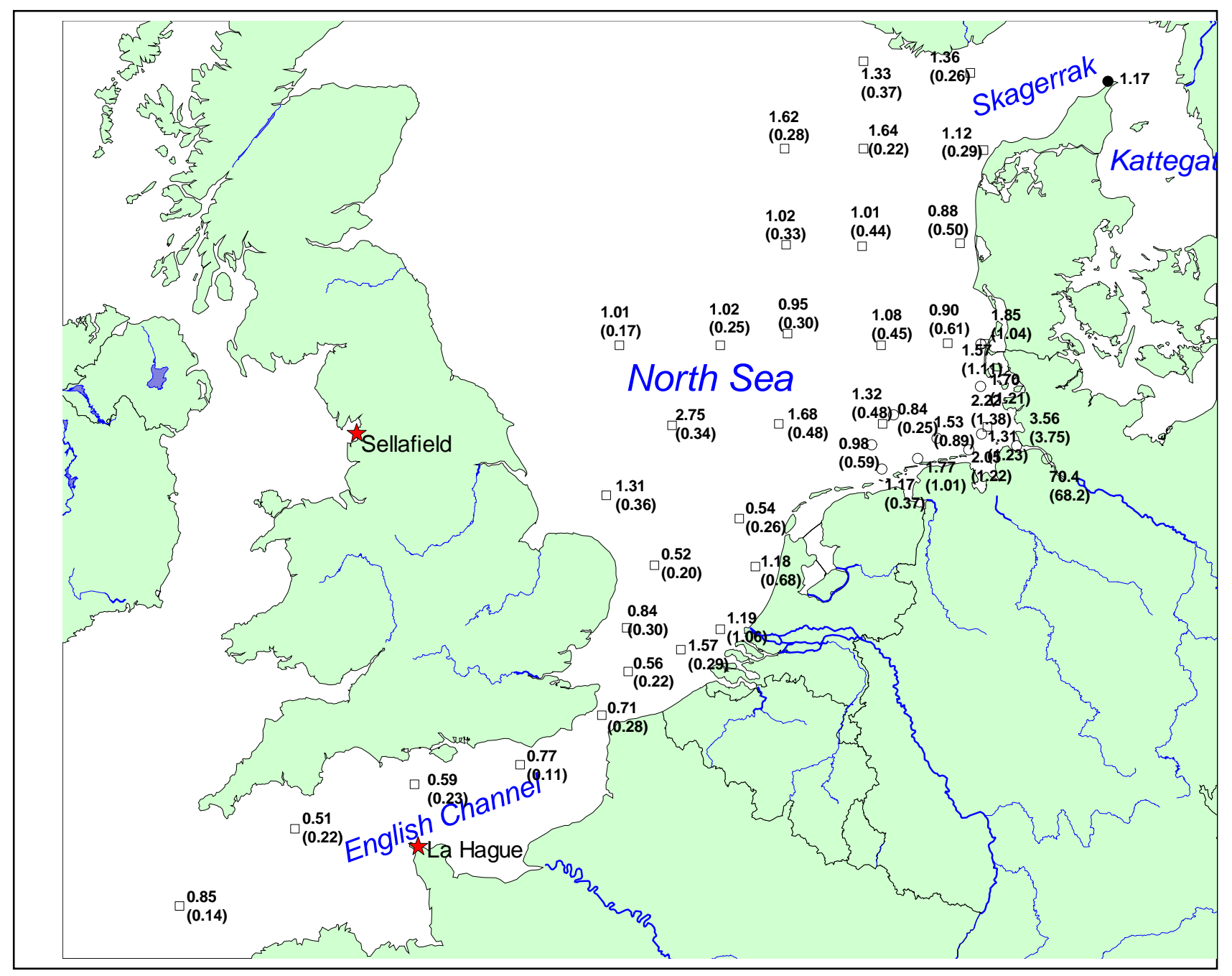

Fig. 7 Distribution of iodide/iodate ratios for ${ }^{129} \mathrm{I}$ (upper number) and ${ }^{127} \mathrm{I}$ (in parentheses) in Seawater from the English Channel and North Sea 


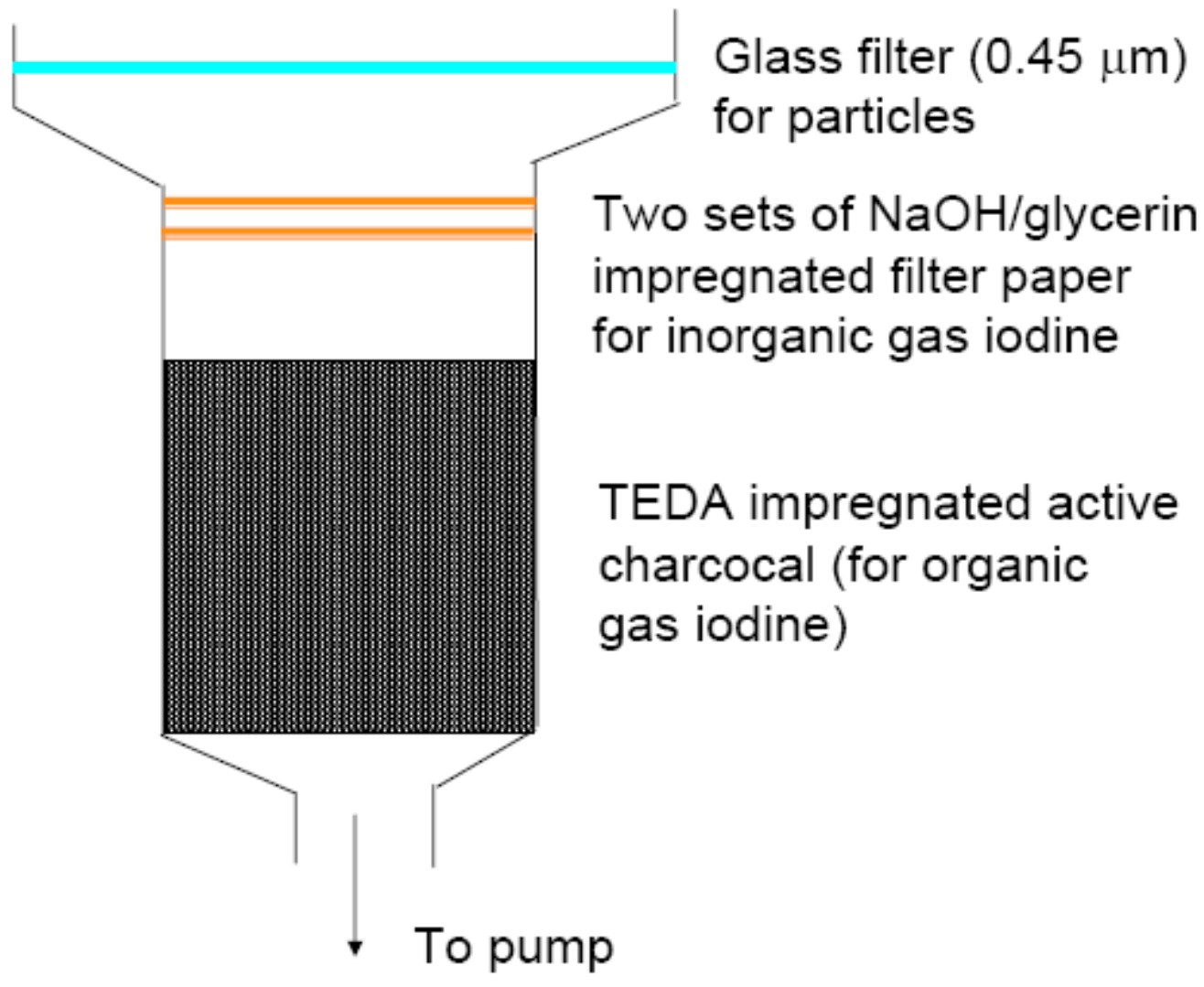

Fig. 8 Diagram of air sampler for collecting particle associated iodine, inorganic gaseous iodine and organic gaseous iodine. 


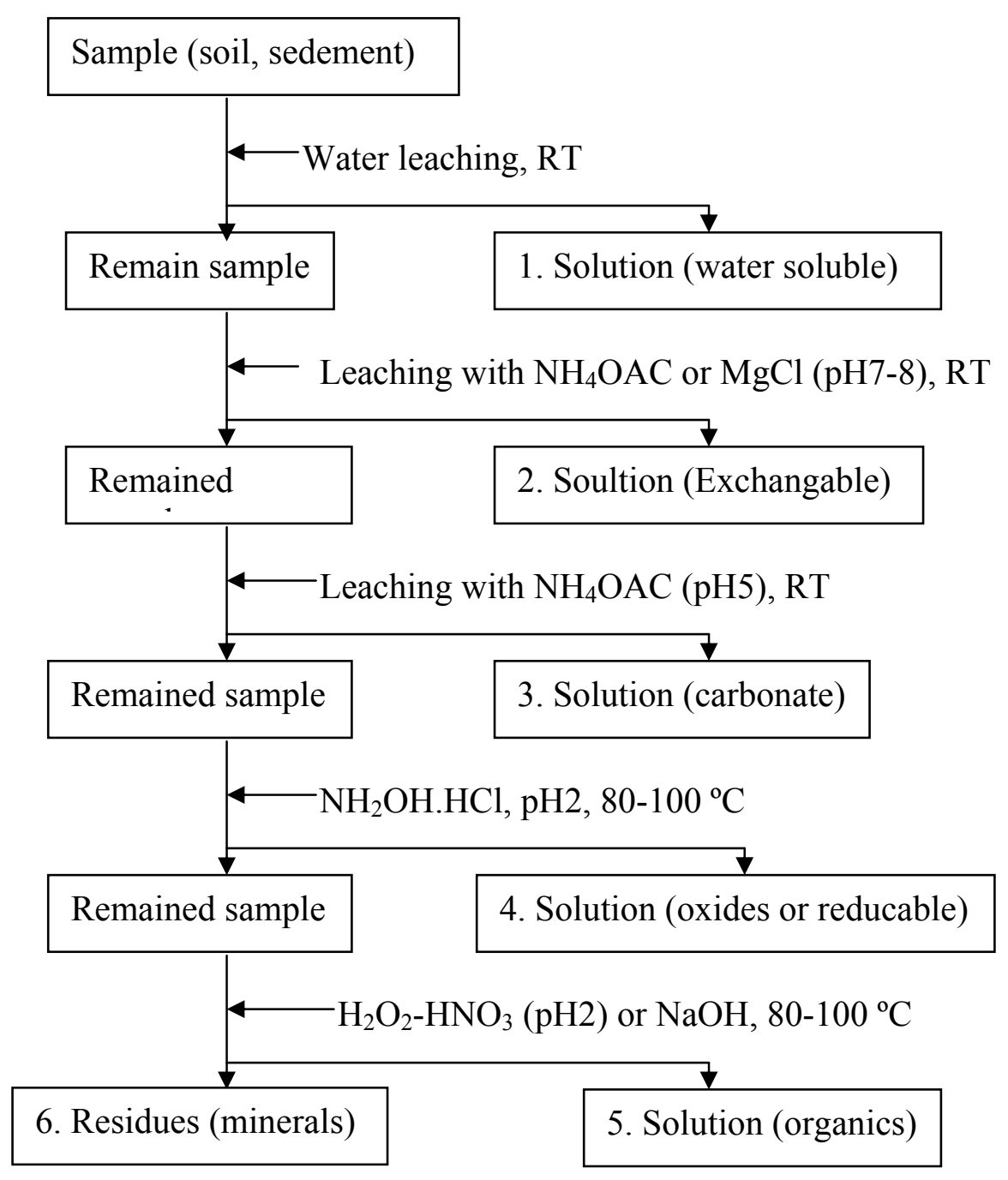
samples

Fig.9 Sequential extraction procedure for fractionation of iodine in soil and sediment 


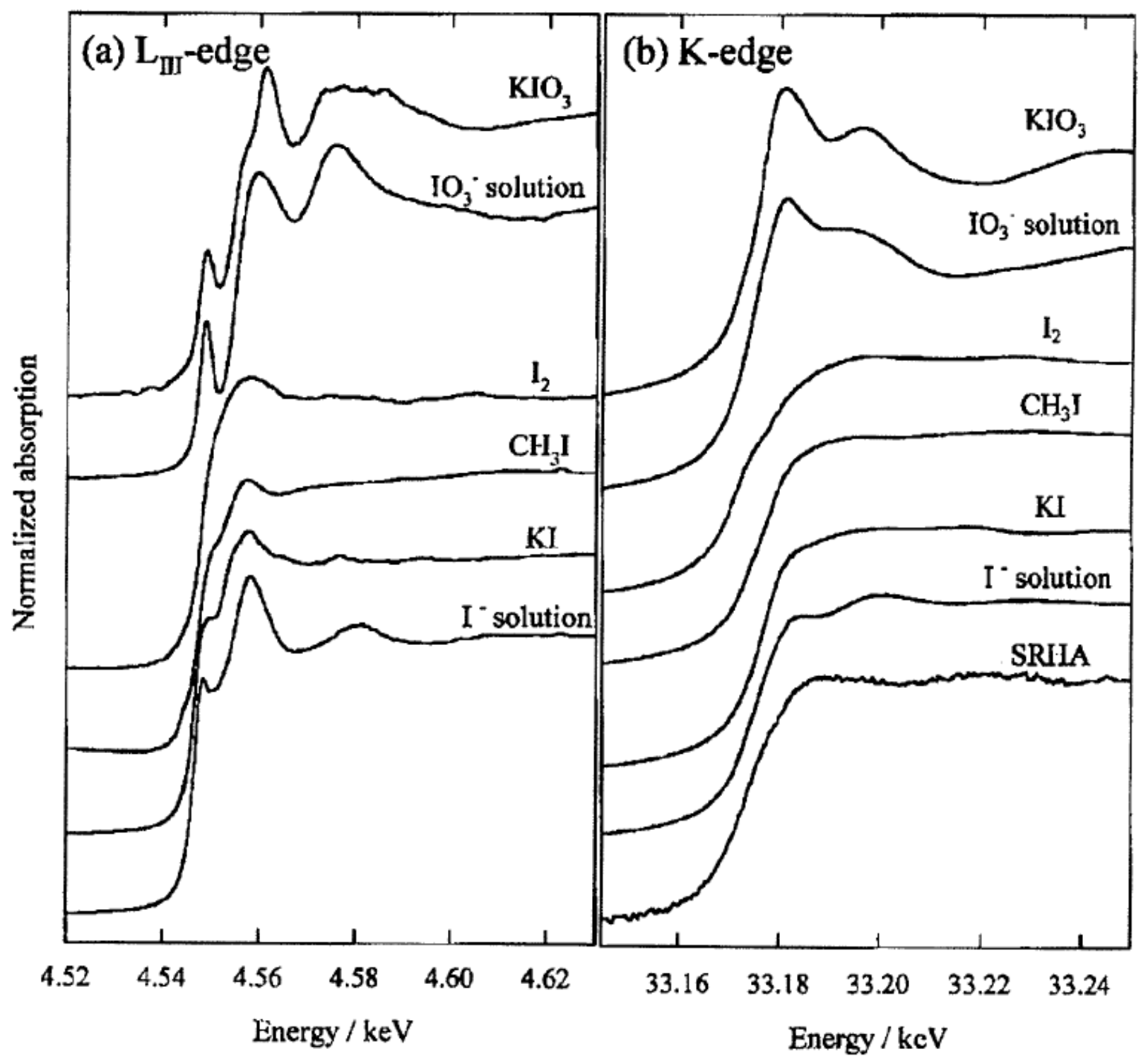

Fig. 10 Iodine $\mathrm{L}_{3}$-edge (a) and K-edge (b) XANES spectra of different iodine species reference materials (Shimamoto \& Takahashi 2008 [153]) 